\title{
Norte da África na antiguidade: os reis berberes númidas e suas iconografias monetárias
}

\author{
Maria Cristina Nicolau Kormikiari *
}

KORMIKIARI, M.C.N. Norte da África na antiguidade: os reis berberes númidas e suas iconografias monetárias. Revista do Museu de Arqueologia e Etnologia, São Paulo, 17: 251-292, 2007.

Resumo: Neste artigo apresentamos nossa interpretação da iconografia monetária dos reis berberes do Norte da África, em particular, dos reis númidas, entre os séculos III e I a.C., sua relação com a cunhagem anterior de Cartago e com a posterior dos romanos. Neste sentido, lidamos com os aspectos ideológicos e culturais que sustentaram essas monarquias norteafricanas da antiguidade.

\footnotetext{
Palavras-chave: Norte da África - Numídia - Moeda - Iconografia Cartago - Roma.
}

\section{Introdução}

\section{O Norte da África durante a Antiguidade e a questão dos povos berberes}

Norte da África representa um rico campo de estudos para as Ciências Humanas, tendo sido, ao longo de vários milênios, objeto de inúmeras transformações culturais impostas por mudanças históricas, ou seja, pela ação do homem. Apesar de fazer parte do continente africano, pode-se considerá-lo, geograficamente, uma "ilha", pois se encontra separado da Europa pelo mar e do resto da África pelo deserto. ${ }^{1}$ As

$\left(^{*}\right)$ Museu de Arqueologia e Etnologia. Pesquisadora do Laboratório de Estudos da Cidade Antiga - LABECA. Professora de Arqueologia ligada ao Archeologos. tanit@usp.br (1) A palavra Maghreb, de origem árabe, atualmente usada para designar a região ocidental do Norte da África, significa literalmente "o tempo e o lugar do pôr-do-sol - o oeste". Para os conquistadores árabes representava a região que era "a ilha pesquisas arqueológicas há muito estabeleceram que desde os períodos mais remotos houve uma série de importantes contatos com o Oriente, muito mais do que com a África central. Igualmente, o material arqueológico encontrado em vários sítios norte-africanos atesta uma série de contatos com a Península Ibérica em particular, mas também com a região mediterrânica central. $^{2}$

Durante a chamada Antiguidade clássica, a região foi colonizada primeiro pelos fenícios e depois pelos cartagineses, que estabeleceram um vínculo cultural permanente com os povos autóctones desta região,

do oeste", isto é, a terra entre o "mar de areia" - o deserto do Saara - e o Mar Mediterrâneo. Esta designação abrange as atuais Tripolitânia, Tunísia, Argélia e Marrocos.

(2) Nas atuais Argélia, Tunísia e Marrocos temos exemplos destes contatos para o período do Ferro e do Calcolítico (ver Camps 1960: 127-145). 
os chamados berberes. ${ }^{3}$ No entanto, gregos e, principalmente, romanos, também ali aportaram. De fato, durante o Império Romano, todo o Norte da África, com exceção do Egito, o qual representava uma unidade imperial a parte, foi transformado em províncias específicas.

O processo de exploração estrangeira do Norte da África não se restringe ao período antigo. Em seguida aos romanos, atesta-se a presença vândala e, na seqüência, islâmica, da região. No período moderno, temos, por fim, a colonização, marcada por momentos de intensa violência, dos europeus, especialmente franceses e italianos.

Neste contexto, os berberes perderam espaço e presença política. Historiograficamente, sua existência terminou pautada e analisada a partir da perspectiva do outro, do estrangeiro. No Maghreb, o processo de independência frente o jugo europeu, que levou a profundas rupturas, gerou uma reconstrução das identidades nacionais. $\mathrm{O}$ passado islâmico foi inicialmente sobrevalorizado, especialmente em relação ao passado da Antiguidade clássica.

Inseridos neste contexto, os berberes também ganharam voz, especialmente após à chamada "primavera berbere", movimento que surge na Argélia, na década de 70, alastra-se pela França, e prega a valorização da cultura berbere, de maneira geral, e particularmente das línguas e da poesia, lutando, inclusive, pela inclusão destas no quadro do ensino escolar argelino.

Entendemos que a determinação da identidade étnica de um povo é uma criação políticosocial, ativada e estruturada através de estratégias

(3) O uso da palavra berbere, descrevendo os habitantes indigenas do Maghreb, surge no século VII d.C. com a chegada dos árabes na região. É possível que a palavra tenha se originado a partir de uma corruptela da palavra latina barbari. Durante o período de ocupação colonial européia sedimentou-se como denominação dos habitantes locais originais. Apesar de poder ser considerada anacrônica foi adotada pela historiografia moderna para designar os habitantes autóctones, visto que foi este o sentido dado a ela pelos árabes. De maneira análoga, a historiografia denomina Berberia o Maghreb, identificando três áreas distintas: Berberia Ocidental (Marrocos e Argélia ocidental); Berberia Central (Argélia central) e Berberia Oriental (leste da Argélia e Tunísia). discursivas dentro do próprio grupo (Hall 1997: 41), ou seja, trata-se de uma construção ditada pelas circunstâncias históricas, de difícil percepção na cultura material. Entretanto, o pesquisador que lida com o Norte da África encontra-se absolutamente familiarizado com a existência de um grupo social específico, os já citados berberes, identificados por meio de aspectos culturais, desde o período proto-histórico, isto é, desde o início da freqüência fenícia na costa maghrebina a partir dos séculos X-IX a.C..

Durante o protetorado francês na Argélia, a arqueologia preocupou-se, principalmente, com a redescoberta do passado romano do Norte da África. Entretanto, alguns pesquisadores franceses e franco-argelinos, como Gabriel Camps (1960, 1961, 1973, 1980, entre outros), Stephané Gsell (1927) e Jehan Desanges (1962, 1983) trabalharam intensamente na recuperação da história berbere. Ainda assim, estes povos não possuíam a primazia nas pesquisas historiográficas que hoje em dia possuem.

Atualmente, a população berbere é minoria no Maghreb, mas a área onde a língua berbere é falada, por outro lado, é imensa, o que pode ser considerado como indicador do tamanho original da população (Mapa 1). Deriva deste traço cultural específico a definição do povo berbere contemporâneo. Isto é, berberes são identificados, principalmente, enquanto povos falando línguas berberes (Brett \& Fentress 1996: 5). Acredita-se que os primeiros proto-berberes tenham surgido no Neolítico, da fusão de três culturas pré-históricas originárias da própria África e do Oriente: os ibero-maurusienses, os capsienses e os neolíticos (Desanges 1983: 429430). Por outro lado, vestígios de uma linguagem comum não são inexistentes. A língua líbica, como é denominada a língua berbere da Antiguidade, chamada de "escrita líbico-berbere", referese a um sistema de escrita encontrado em inúmeros documentos no Norte da África, no Saara e nas Ilhas Canárias. Os lingüistas são unânimes quanto à sua unidade original, depois fragmentada em alfabetos diferentes, mas correlatos, no período histórico (época da colonização cartaginesa, isto é, a partir do século $\mathrm{V}$ a.C.) e que pertenceriam a grupos indígenas específicos (Galand 1989: 69). 


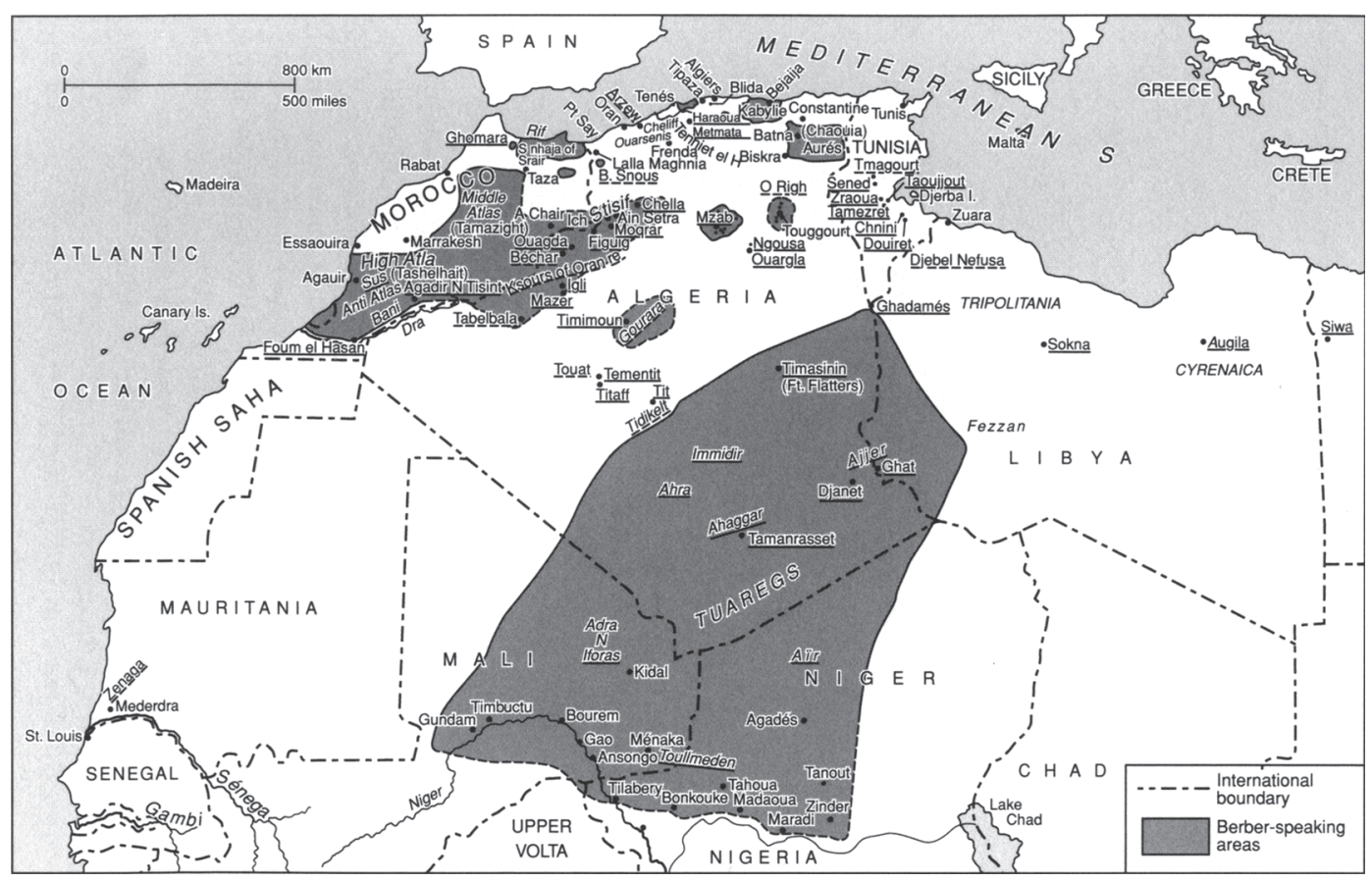

Mapa 1. Distribuição dos dialetos berberes modernos. Brett \& Fentress 1996: 2.

Conforme visto à nota 3, o termo berbere, por sua conta, não é autóctone. Mesmo atualmente os povos berberes possuem outra auto-denominação dialetal: tamazight, para a língua, e imazighen, para o povo a utilizá-la. Este termo seria derivado da palavra amazigh, aparentemente o nome utilizado pelos próprios berberes como designação étnica de seus grupos indígenas na Antiguidade. Este surge em inscrições líbicas na forma MSK e em inscrições romanas nas formas Mazic, Masik, Mazix e Mazica (Gsell 1927, vol.V: 116; Camps 1960: 27).

Temos estabelecido, assim, a existência de uma população autóctone norte-africana, para a qual a historiografia moderna adotou o nome berbere apesar de este não ser o seu nome original. Mas como mencionamos no início de nossa introdução, o povo berbere não se desenvolveu em um vácuo, sua história necessita ser analisada dentro de um contexto histórico maior, norte-africano. Ou seja, com relação à Antiguidade, primeiro tendo-se em mente os contatos com a Bacia Mediterrânica, depois em relação aos colonizadores fenício- cartagineses, e, por fim, aos romanos. No entanto, esta mesma necessidade básica originou duas distorções; primeiro, que a História do Norte da África tivesse a tendência de ser uma história a relatar os eventos de seus conquistadores; segundo, que os berberes tenham sido tratados quase como povos ahistóricos, sem história.

Neste sentido, um grande empecilho é sem dúvida a escassez de documentação direta. A história e a organização social dos berberes na proto-história é praticamente desconhecida. Os dados que possuímos sobre eles são, na sua imensa maioria, de ordem material e, mais especificamente, relacionados à esfera excepcional da morte. Ou seja, possuímos um quadro razoavelmente completo dos tipos de túmulos e áreas de enterramento desses povos (Camps 1961). No entanto, as formas de ocupação espacial e a cultura material a elas relacionadas ainda não foram estudadas de maneira a formar um corpus documental consistente.

Sua língua, a líbica, só ganhou um formato escrito em torno do século IV a.C., ou seja, já no período histórico, após contatos mais 
extensos com os fenício-cartagineses e com a língua destes, o púnico.

Possuímos, por outro lado, relativamente poucos textos líbicos da Berberia. A grande maioria deles são inscrições de caráter religioso, bilíngües com o púnico ou neo-púnico (forma cursiva do púnico) (Galand 1989: 70). A língua líbica ainda não foi totalmente decifrada.

As fontes escritas mais prolixas sobre os autóctones continuam sendo os textos de autores gregos como Heródoto, Diodoro da Sicília, Ptolomeu e Políbio, e romanos como Salústio, Tito-Lívio, Plínio, o Velho, Tácito e Apiano, entre outros. Deste modo, no que toca à documentação textual o que possuímos são informações por vezes anacrônicas e parciais.

Assim, a Arqueologia e a Etnologia têm sido as duas ciências que mais se aprofundaram no conhecimento acerca dos berberes. $\mathrm{O}$ paralelo etnológico tem sido muito utilizado e é, de fato, uma abordagem extremamente útil. Mas é preciso escapar da crença na "permanência berbere", ideário que alcançou grande influência na historiografia moderna (Brett \& Fentress 1996: 6-7).

A idéia da permanência berbere nasceu não só da recorrência, em relatos distribuídos ao longo do tempo, de certos temas que foram caracterizados como tipicamente berberes família, clã, tribo, ausência de estado, apego à liberdade, entre outros -, como também foi sustentada pelos próprios dados arqueológicos. Como mencionado, o material de estudo mais relevante da Arqueologia proto-histórica no Maghreb são os monumentos funerários. Isto porque os locais de moradia protohistóricos ou são desconhecidos, ou são de difícil identificação no meio de ruínas sem características distintivas, de todas as épocas (de época romana até muitos séculos anteriores), que, por comodidade, são designadas como "ruínas berberes" (Camps 1960: 90-96). Gabriel Camps (idem: 96) chama de "permanência berbere" justamente o fato de as técnicas de construção e a cultura material cotidiana, no grande espectro, não terem se modificado significativamente ao longo dos séculos, o que dificultaria a diferenciação por períodos.

A homogeneidade no tempo de parte significativa da documentação material berbere levou, portanto, à crença de que as instituições políticas, econômicas e sociais tivessem igualmente permanecido homogêneas. Deste modo, um estudo etnográfico acerca de uma população berbere da atualidade poderia ser transplantado para a Antiguidade. A circularidade desta proposta é evidente: se procurarmos por berberes, durante o período romano por exemplo, apenas em vilarejos nas montanhas, que é onde eles estão ainda hoje, será fácil, mas dificilmente legítimo, demonstrar que os berberes da Antiguidade eram idênticos aos habitantes modernos dos Montes Aurés ou da Kabília.

No entanto, o cuidado no trato dos dados etnográficos, evitando-se a transposição pura e simples, principalmente geográfica, dos berberes medievais e modernos para a Antiguidade permite que as pesquisas etnológicas sejam de grande valia. Isto porque os berberes podem ser estudados a partir da chamada longa duração, da História lentamente ritmada (Whittaker 1993 (1978): 331).

$\mathrm{Na}$ esteira dessa proposta, os berberes de todos os tempos são mormente identificados como uma sociedade tribal, definição que a Etnologia comprova. Com relação à Antiguidade, entretanto, este dado vem notadamente das fontes textuais, onde as "tribos", isto é, os grupos indígenas, são apresentados de forma antinômica, isto é, ou são nômades ou são sedentários.

Já a partir da II a Guerra Púnica, os grupos indígenas berberes aparecem mencionados nas fontes enquanto entidades históricas: Plínio afirma que 463 desses grupos juraram fidelidade a Roma (H. N. 5, 1). Baseados nos poucos dados sócio-políticos que os textos gregos e latinos nos fornecem a respeito dos berberes, e aliando estes dados aos estudos etnográficos mencionados acima, há uma forte tendência na atualidade em visualizar os berberes enquanto organizados em grupos clãnicos agnatícios, isto é, que descendem de linhagem masculina, transmitida de varão a varão (Whittaker 1993 
(1978): 336). Vilarejos seriam compostos por estes grupos agnatícios, de famílias extensas subdivididas em clãs. A tendência destes clãs em entrar em desacordo impediria a formação de unidades espaciais muito grandes, restringindoos a agrupamentos menores, vilarejos. A própria organização destes vilarejos seria difícil em razão desta falta de união (Brett \& Fentress 1996: 33).

Entre os séculos IV e III a.C., as fontes textuais e parte da cultura material, notadamente no campo da numismática, apontam para uma profunda mudança no modo de viver berbere. Neste período, justamente, temos o início dos embates entre púnicos e gregos na Bacia do Mediterrâneo setentrional e também no Norte da África (guerra contra Agátocles, tirano de Siracusa), e das guerras com os romanos, as chamadas Guerras Púnicas. Para esse período, portanto, a documentação textual e material dá conta da formação de reinos próprios entre os berberes. Estes reinos teriam sido baseados em coligações de vários grupos indígenas, em uma dada área, sob a liderança de um grupo agnatício específico, pertencente a um dos grupos indígenas da coligação (Camps 1960; Desanges 1980; Fentress 1982).

Assim, três linhagens são traçadas: a dos mouros na Berberia Ocidental (atual Marrocos e oeste da Argélia) e parte ocidental da Berberia Central (Argélia); a dos masesilos na Berberia Central (Argélia) e a dos massilos nas Berberias Central e Oriental até a fronteira com Cartago primeiro e depois com a província romana Africa (leste da Argélia e oeste da Tunísia). Esta última dinastia, a dos massilos, é a de Massinissa, o mais renomado dos reis berberes. Teria sido a mais bem sucedida, com uma linhagem de uma única família agnatícia dominando o poder do século III a.C. até o século I a.C.. Massinissa foi um grande aliado romano, responsável direto pela derrota e destruição de Cartago na batalha de Zama, em 202 a.C., e o formador do grande reino númida, que acabou englobando sob esta denominação os antigos reinos masesilo e o seu próprio, o massilo. A Numídia corresponde, de maneira geral, a área destes dois reinos.

Paralelamente aos extensos relatos de autores como Tácito, Lívio, Salústio e outros, a documentação material mais importante a atestar a presença e influência das dinastias berberes é, conforme mencionamos acima, a cunhagem monetária própria destes reis. As moedas dos reis berberes podem ser encontradas não apenas ao longo de todo o Maghreb, como também em terras mediterrânicas setentrionais, notadamente nas regiões de origem dos mercenários dos exércitos romanos e berberes (Kormikiari 2000: 304-367). Os reis berberes são tratados como reis aliados dos romanos e serviram de apoio militar e econômico nas incursões romanas contra Cartago no Norte da África, como também tiveram papel importante no desenrolar das guerras civis romanas que culminaram com a ascensão de Otávio no século I a.C.. Mas não apenas a moeda é testemunho, no campo material, dessa presença: várias inscrições líbicas, muitas delas bilíngües, e outras latinas e gregas mencionam os reis (Camps 1960: 216; Gsell 1927, vol.VI: 130-131; Carcopino 1943: 285); encontramos, ainda, grandes monumentos funerários, que se acredita erguidos em sua homenagem, como a Tumba da Cristã e o Medracen (Coarelli \& Thébert 1988). Além disso, os textos antigos mencionam diversas capitais e cidades reais berberes, Volubilis e Banasa na Berberia Ocidental, Siga, também na Berberia Ocidental, Iol (Cesarea, atual Cherchel) na Berberia Central, Cirta (atual Constantina) na Berberia Oriental, entre outras. Um aspecto muito importante da ocupação romana no Maghreb foi assinalado pelo arqueólogo de Volubilis, André Jodin (1987: 26): "No Marrocos, cada cidade romana está localizada sobre uma cidade púnico-moura e, até o momento, não houve exceção para essa regra”.

A Arqueologia redescobriu, no Maghreb, diversas aldeias ou vilarejos berberes antigos. Muitos destes continuaram a ser habitados no período romano, e mesmo mais tarde. Muitas vezes, inclusive, são usados até os dias atuais, pois as fontes de água - razão primordial para a criação do assentamento naquele local específico - continuam ativas.

No entanto, mesmo após a descoberta arqueológica de importantes centros urbanos púnico-berberes, a maioria dos estudiosos 
sustenta a teoria, apenas delineada pela Arqueologia, e basicamente sustentada pelos dados textuais da Antiguidade e pelos dados da Etnologia, de que a maioria da população indígena continuou a habitar as aldeias, principalmente nas regiões montanhosas da Kabília e do Aurès (Berberias Oriental e Central); e do Rif, do Médio e do Alto Atlas (Berberia Ocidental) (Gsell 1927, vol. V: 251; Camps 1960; Rossetti 1960; Isserlin 1983; Smadja 1983). ${ }^{4}$

Um redimensionamento possível desta teoria foi apresentado por André Jodin (1987: 56-63). Este arqueólogo acredita ser possível lançar a hipótese de que cada cidade interiorana da Berberia Ocidental (a colonização feníciopúnica tendo a característica de se restringir à costa), antes de ser romanizada, foi um centro nevrálgico ou um oppidum de um grupo indígena berbere. Volubilis, Gilda, Sala, Banasa, entre outras, longe de terem sido cidades isoladas no meio de uma população estranha, autóctone, mais e menos hostil, cidades fechadas dentro de suas muralhas e sem possuírem recursos definidos, eram, para Jodin, centros políticos, econômicos e religiosos de seus "Estados" respectivos, nos quais uma administração punicizada reinava sobre uma sociedade autóctone.

O presente artigo, baseado em parte das conclusões a que chegamos em nosso trabalho de doutoramento (Norte da África autóctone do século III ao I a.C.: as imagens monetárias reais berberes, 2000), apresenta uma análise da iconografia monetária real berbere númida, a qual demonstra, tanto pela imagética utilizada, quanto pelos metais e volume de emissão adotados, as relações ambíguas que pautaram o viver berbere frente os invasores estrangeiros,

(4) À falta de uma precisão espacial estabelecida pelos dados materiais, costuma-se utilizar, para a análise do padrão de assentamento dos berberes, dados retirados das fontes textuais. De maneira geral, percebemos o uso indiscriminado de termos significando aldeia e/ou vilarejo: castellum (Salústio, Jug., LIV, 6; LXXXVII, 1; Bell. Afric., II, 6; Vi, 6; Tito-Lívio, XLII, 23; Justino, XXII, 5, 5; e outros), vicus (Tito-Lívio, XXIX, 30, 7) e chomí (Apiano, Lib., 12). O termo oppidum, que por vezes acompanha castellum, é interpretado como designando cidades fortificadas (Tito-Livio, XLII, 23). e as transformações sócio-econômicas que se processaram a partir destes contatos. ${ }^{5}$

A cunhagem norte-africana, excluindo a região de Cirene, que possui um percurso dissociado, é dividida em certos períodos chave. Entre esses momentos, cruciais para a história do Norte da África na Antiguidade, os reinos indígenas emitiram as suas cunhagens. As diferentes emissões estão ligadas umas ao primeiro período histórico, e outras ao segundo. Essa ligação é de cunho político e econômico e, portanto, cultural. A organização social berbere baseada em famílias agnatícias, com chefias locais, data de muito antes da formação dos reinos centralizados no final do século III a.C.. ${ }^{6} \mathrm{Na}$ prática, a existência desses reinos autenticamente berberes termina no reinado do mouro Boco II em 33 a.C., um pouco antes da ascensão ao poder do primeiro imperador romano, Augusto, e quase um século antes da anexação definitiva e oficial de toda a Berberia por parte de Roma. O último rei númida conhecido, Mastenissa II ou Arabion, havia sido deposto pelos romanos em 41 a.C.. De fato, entre a II ${ }^{a}$ Guerra Civil romana, em 49 a.C., e a subida efetiva ao poder de Augusto, em 27 a.C., a presença política das partes envolvidas nos assuntos africanos demonstra o quanto irreversível era o

(5) São conhecidos, a partir das fontes textuais e epigráficas, 26 reis berberes. No entanto, nem todos possuem cunhagem própria identificada. $\mathrm{O}$ dado negativo, aqui, não significa, necessariamente, que estes reis não emitiram numerário, e sim, que suas moedas ou perderam-se ao longo dos séculos ou ainda não foram recuperadas arqueologicamente. Apresentamos, neste artigo, as moedas da dinastia mais duradoura e poderosa, a dos númidas.

(6) Apesar de crermos em uma centralização lassa, a emissão de numerário próprio é o dado mais significativo da transformação das chefias nessa sociedade berbere tribal. Lembramos que a moeda tem como característica principal a de ser um produto oficial, garantido pelo estado ou governo que a cunhou. $\mathrm{Na}$ Antiguidade, na imensa maioria das vezes (as exceções ocorreram em momentos específicos, de crise político-econômica profunda), ela possui um valor intrínseco, e é esse valor que é garantido pelo poder emissor. 
caminho que já vinha se delineando há muitas décadas, através da presença constante dos negotiatores italianos e também da comunidade grega na Berberia. Nossa proposta neste artigo é a de, por meio da análise iconográfica dos tipos monetários reais berberes númidas, analisar como se deu a evolução interna das cunhagens, de um rei para o outro, e procurar o entendimento de como eles responderam à presença cada vez mais marcante dos futuros poderosos da Berberia. Por fim, à luz dos dados que conseguimos coletar acerca da circulação monetária berbere, os quais apresentamos à medida que discutimos a análise dos tipos iconográficos, teceremos alguns comentários sobre a relação emissor e receptor.

\section{Parte I}

\section{Berberia Púnica}

O primeiro período chave abarca quase três séculos e corresponde aos inícios da monetarização da Berberia. As primeiras emissões monetárias batidas em solo africano foram cunhadas, no final do século IV a.C., por Cartago. O mais recente artigo acerca do conjunto numerário cartaginês, publicado pelo numismata Paolo Visoná, que desenvolve, há muitos anos, uma pesquisa sistemática sobre a localização das oficinas monetárias cartaginesas, propõe que a primeiríssima cunhagem batida em solo africano seja uma emissão em bronze, extremamente difundida pelos territórios púnicos da Sicília, Sardenha e Berberia. Essas moedas trazem como tipo iconográfico de anverso uma cabeça masculina enfeitada com grão de trigo e brinco (Triptolemos?), e no reverso um cavalo correndo livre (Visonà 1998: 5).

Do século IV até c. o início da II ${ }^{a}$ Guerra Púnica (218-202 a.C.), apenas Cartago emite numerário na Berberia. Durante boa parte desse período, a capital africana instituiu um sistema monetário coeso e homogêneo por todos os seus territórios, tanto em bronze (unidades e frações), como em prata, ouro e eletro. No entanto, entre as duas guerras púnicas (264 a.C. e 202 a.C.), padrões regio- nais de circulação podem ser percebidos através da análise dos locais de achados monetários. As moedas cunhadas nas oficinas espanholas, entre 237 e 206 a.C., não são normalmente encontradas no Norte da África, e muito poucas peças cunhadas nas oficinas de Cartago, entre 238 e 220 a.C., aparecem em escavações ou achados esporádicos do outro lado do Mediterrâneo (Visonà 1998: 16).

O sistema de cunhagens adotado por Cartago a partir de c. 200 a.C. foi resultado de uma reforma monetária, conseqüência de sua derrota na II ${ }^{a}$ Guerra Púnica. Cartago praticamente abandona a cunhagem em metais preciosos e passa a emitir apenas em bronze. Desse modo, são batidas duas emissões de $c$. 20 e $100 \mathrm{~g}$, possivelmente representando uma unidade e um múltiplo. As séries mais leves trazem como tipo monetário de anverso a cabeça da divindade Core/Tanit, e no reverso um cavalo dando passo à direita. Já nas séries mais pesadas há dois tipos de reverso: com o cavalo parado ou dando passo à direita, sempre com um disco solar, flanqueado pelo uraeus cobra. A hipótese mais trabalhada é que Cartago tenha feito uso das peças de $100 \mathrm{~g}$ como meio de substituição das divisões de prata menores que ela não mais podia cunhar (Alexandropoulos 1989: 535).

Entre c. 200 a.C. e 146 a.C., a circulação monetária em Cartago estava baseada essencialmente nessas emissões e em algumas séries de bronze mais antigas que nunca saíram de circulação (Visonà 1998: 21, nota 64).

Após 146 a.C. o numerário cartaginês desaparece, em geral, da estratigrafia arqueológica, provavelmente porque foi derretido. No entanto, as últimas emissões cartaginesas de bronze, que discutimos acima, continuam sendo encontradas, ainda que em quantidades muito pequenas, em sítios norte-africanos, mas mormente em contexto tardio (Visonà 1998: 23, nota 69; Fischer 1978: 37).

\section{Berberia entre as Guerras Civis Romanas e o Principado de Augusto}

O segundo período chave concerne à presença dos exércitos romanos e de seus 
magistrados moedeiros em solo norte-africano, por ocasião das disputas internas na Roma Republicana. Disputas, cujos combates militares foram, muitas vezes, travados em territórios estrangeiros, na Berberia, na Península Ibérica, no Egito.

A destruição de Cartago e a criação simultânea da província Africa em solo púnico acarretaram uma mudança decisiva na relação entre as forças políticas da Berberia. T. Kotula afirma que o estado cartaginês havia, já há séculos, se tornado africano, isto é, berbere. No entanto, este estado foi, após a destruição da capital africana, o praedium populi Romani, o solo provincial do inimigo estrangeiro (Kotula 1976: 338). O reino númida faz, agora, fronteira com o território ocupado pelos romanos. Estudos recentes têm procurado demonstrar o complicado jogo político e econômico romano, à época dos Gracos e durante a derrocada da República, ao longo das acirradas disputas entre os optimates e os populares. T. Kotula defende a tese de que a Guerra de Jugurta, travada entre o autoproclamado rei númida Jugurta e Roma, teve como causa as incessantes intervenções do poder romano nas sucessões dinásticas berberes. Paralelamente, este interesse romano nas questões políticas locais estava relacionado aos interesses econômicos dos homens de negócio italianos, os negotiatores, atuando nas cidades fenício/cartaginesas e berberes, incluindo nas chamadas "capitais" dos reinos, como em Cirta, a mais importante delas.

A vitória de Mário, na Guerra de Jugurta, permitiu que o partido dos populares levasse a cabo sua política de doações de terras férteis, longe da Itália, aos veteranos. Uma série de inscrições africanas, encontradas em território númida, atesta que a lex Appuleia, de 103 a.C., que designava para cada veterano de Mário 100 ingera (c. 25 ha), utilizou terras não pertencentes à província Africa, o que, na opinião de T. Kotula significa que a Numídia estava cada vez mais submetida a Roma (Kotula 1976: 339). Essas anexações de terras númidas teriam sido feitas nas terras do rei Gauda. Entretanto, lembramos que a historiografia moderna não chegou ainda a um denominador comum quanto à posse privada da terra entre os berberes. A partir dos estudos etnográficos a tendência é acreditar-se em posse compartilhada, paralelamente à existência de privilégios por parte do chefe, do rei (Whittaker 1993 (1978): 341). Outros pesquisadores (Gsell 1927, vol.V; Smadja 1983; Kotula 1976) defendem uma crescente privatização das terras por parte de uma elite berbere, que se constitui ao longo dos séculos III e II a.C. e que entra, desse modo, no mesmo âmbito de atuação das elites cartaginesas, dos libifenícios. E. Fentress acredita ainda que as populações númidas, tanto sedentárias quanto semi-nômades, eram contra as anexações de terras e as taxações feitas, seja pelos reis númidas, seja pelo poder romano (Fentress 1982: 333).

Acreditamos, de fato, ser mais plausível manter a visão de uma sociedade multi-facetada: urbana ao longo do litoral mediterrânico (a imensa maioria das cidades conhecidas do período fenício-cartaginês está localizada ao longo da costa marítima); sedentária e agrícola para o interior; semi-nômade, principalmente em direção à zona desértica (mas com uma grande variação de percurso territorial, tanto na direção norte-sul, como leste-oeste). É justamente no âmbito urbano que os contatos entre autóctones e estrangeiros, notadamente os libifenícios, mas também iberofenícios, italianos, romanos e gregos foram mais intensos.

Os dinastas númidas da época ${ }^{7}$ alinharamse com os diferentes partidos romanos em luta civil. A questão básica por detrás desses apoios parece ser a da posse da terra. Gauda teria tido as terras, sobre as quais mantinha sua autoridade, confiscadas, pois conforme visto acima, o partido dos populares preconizava o uso dessas terras para Roma. Já o partido dos optimates teria interesse em manter o status quo na Berberia, seja em razão do poder dos reis indígenas de arregimentar tropas; seja por interesses econômicos - o comércio dos cereais nas mãos dos negotiatores na Numídia e

(7) Incluindo o usurpador Hiarbas, que se acredita ter sido, provavelmente, de origem getula, grupo berbere habitante da zona meridional do Maghreb (Kormikiari 2000: 189-225). 
o comércio de produtos de luxo na Mauritânia (Fentress 1982: 330). Quer tenham tido a posse real das terras ou as tenham compartilhado com os chefes menores dos vilarejos, com os membros da família agnatícia a qual pertenciam, e/ou com as próprias populações númidas, acreditamos que os reis berberes efetivamente foram os mediadores entre estes agentes e o poder cartaginês, primeiro, e romano, em seguida. No entanto, quando as disputas internas romanas foram transportadas para o território norte-africano, o interlocutor estrangeiro, com quem os reis tinham que se entender, deixa de ser claro e uno. Entra em cena o jogo político externo, ao qual se aliam as questões internas (tanto em relação às populações das cidades, estrangeiras e locais incluindo os descendentes dos cartagineses, como as populações dos vilarejos, das planícies). Justamente acerca das questões internas é que nossa documentação é mais falha. A partir dos dados de circulação que apresentamos adiante, cremos poder comprovar que a circulação monetária concentrou-se nas áreas urbanas, litorâneas na sua maioria, e também nas mãos dos componentes estrangeiros dos exércitos. Acreditamos que a circulação entre os berberes ocorreu mais no nível das chefias, e não entre as populações propriamente ditas. A vitória de Pompeu em 81 a.C. representou a sustentação da política dos optimates e retardou uma colonização romana mais acentuada no Norte da África, ao menos até a vitória, quase quarenta anos depois, de César em Tapso. Nesse momento, então, temos a anexação definitiva das terras númidas, transformadas na província Africa nova. ${ }^{8}$

O período, portanto, que vai da destruição de Cartago à anexação da Numídia (146 - 46/ 41 a.C.) corresponde aos reinos de praticamente todos os reis númidas (incluindo o getulo Hiarbas), as únicas exceções são com relação

(8) Os dois últimos reis númidas, Arabion e Juba I, ficaram do lado dos pompeianos. Na opinião de T. Kotula (1976: 339), César agia à luz do caráter cada vez mais expansionista da República Romana e teria seguido, de maneira geral, a linha do partido dos populares, e no que toca às questões norte-africanas, a politica marianista. aos dois primeiros reis de que temos notícia, Sifax e Massinissa. É, portanto, um momento muito importante em nossa análise, principalmente porque, colocando-o em contraponto ao primeiro período exposto acima, percebemos que a economia monetária da Berberia se transforma por completo. As antigas cunhagens púnicas são substituídas, com exceção dos bronzes dos reis e das excepcionais cunhagens em prata de alguns destes, pelo numerário romano (com um sistema monetário próprio e que será copiado, posteriormente, pelos reis).

No que toca especificamente à questão da circulação monetária no Norte da África podemos dizer que após a destruição de Cartago, em 146 a.C., houve uma mudança radical na circulação de metais preciosos na Berberia. A cunhagem em ouro desapareceu e aquela em prata foi substituída pelos denários romanos. Sabe-se que uma carga de denários foi mandada para a África, oficialmente, em 111-110 e outra também em 82 a.C. (Amandry; Burnett \& Ripollès 1988: 182).

Durante a Guerra Civil entre César e Pompeu, ambas as partes cunharam moedas na Berberia. Denários foram emitidos por Metelo Pio e Cato em 47-46 a.C. e pelo rei númida Juba I, talvez na antiga colônia fenícia de Útica, para ajudar a causa de Pompeu. Juba I também produziu sestércios e quinários e sua contribuição foi de tamanho mais que razoável. Do outro lado, os que apoiavam César também devem ter cunhado peças. Bogud, rei mouro da Mauritânia ocidental, o apoiou: suas moedas, apesar de produzidas em pequenas quantidades, são denários em todos os aspectos (metrológicos e iconográficos).

Depois da vitória de César em Tapso, a província romana Africa foi reorganizada, quando então Roma se apoderou de parte da Numídia. Depois de 42 a.C., quando Q. Cornifício, governador da Africa vetus, cunhou áureos e denários, não se bateram mais peças de prata no Norte da África, com exceção de uma pequena emissão da cidade fenícia de Leptis Magna, posterior ao ano 15 a.C. (Amandry; Burnett \& Ripollès 1988: 182).

Por fim, um terceiro período, que acreditamos poder ser incluído como seqüência do 
período apresentado acima, pois em termos numismáticos corresponde à continuação dos sistemas monetários romanos, é representado pelo triunvirato de Otávio, Lépido e Marco Antônio, e culmina com a ascensão ao poder de Otávio, que assume o título de Augusto e se torna o primeiro imperador romano. No entanto, uma vez anexados os territórios orientais da Berberia, o único reino berbere que sobreviveu foi o dos mouros. Dos soberanos mouros que pudemos assinalar, apenas os dois últimos, Boco II e Bogud, cunharam numerário próprio. Este numerário é igualmente devedor, em termos ponderais, das cunhagens romanas, como mencionamos acima.

Augusto acelerou o processo de colonização das terras africanas. Este movimento populacional já havia se iniciado desde a destruição de Cartago (lembramos apenas a tentativa dos irmãos Graco em refundar Cartago, e os assentamentos de veteranos durante as Guerras Civis). Na Berberia Oriental, isto é, na província unificada que juntou a Africa vetus e a Africa nova, e para além, na região das Sirtes (atual Líbia), Augusto não interferiu nos estatutos políticos das cidades livres, principalmente dos portos. Já nas regiões interioranas, ele instalou veteranos da XIII" legião (C.I.L. VI, 36917, apud Lassère 1982: 415) em Thuburbu Minus, Thuburbi Maius, Suturnuca, Medeli, Assuras, Simithus, Thuburnica e Sicca Veneria. Outras cidades como Vaga e Cirta receberam mais colonos. Os habitantes berberes dessas regiões entravam em contato com essas novas instalações, principalmente nos dias de mercado, quando desciam de suas castella para se dirigir às nundinae (mercados periódicos).

Nas Berberia Ocidental e Central, região que ainda não havia sido transformada em província romana, Augusto igualmente procedeu à instalação de veteranos. São doze as colônias ali estabelecidas: 3 no oeste, com os nomes de Iulia, 9 no leste, com o nome de Iulia Augusta (Mackie 1983: 337-338).

Como salientamos acima, durante o reinado de Augusto na Berberia apenas o bronze era cunhado. É preciso lembrar, no entanto, que durante os reinos indígenas não foram apenas os reis que emitiram numerário próprio, várias cidades fenício-cartaginesas e berberes, igualmente o fizeram. Entretanto, trata-se de uma cunhagem com volume de emissão extremamente baixo (alguns tipos são conhecidos por meio de exemplares únicos), de metal não precioso, e produzida para circulação apenas local (ao menos é o que se pode depreender a partir dos poucos dados de circulação disponíveis) (Kormikiari 2000: 276304). Ainda assim, fazem parte, portanto, de um mesmo momento histórico e se relacionam entre si. Conforme mencionamos anteriormente, o último rei indígena númida conhecido, Arabion, é deposto em torno de 41 a.C.. A partir desta data, até o principado de Augusto, somente as cidades vão manter sua produção monetária na Numídia e na província Africa. No entanto, na Mauritânia, além das cidades, vão se manter as cunhagens dos dinastas mouros até c. 33 a.C..

Antes de iniciarmos a análise das cunhagens reais propriamente ditas, gostaríamos de tecer algumas considerações acerca das cunhagens citadinas. $\mathrm{O}$ primeiro dado marcante que temos é a dicotomia entre as cunhagens citadinas pré-romanas e as pós-Augusto. As diferenças não são apenas de ordem iconográfica (aí incluindo estilo, textura de fabricação e tipos), mas também no que toca aos sistemas monetários. De maneira geral, as mesmas incertezas que possuímos com relação ao sistema ponderal do bronze cartaginês prevalecem com relação às ditas cunhagens neo-púnicas. Já as peças cunhadas nas colônias romanas e nas cidades elevadas a município por Roma seguem, de maneira geral, o sistema monetário romano, acompanhando inclusive as reformas monetárias instituídas por Augusto em c. 20 a.C..

Um outro ponto marcante diz respeito à iconografia e à epigrafia. As peças mais antigas, da Berberia Central notadamente, parecem reproduzir um imaginário religioso de caráter fortemente fenício-púnico. Constituem uma excelente fonte documental a respeito da 
imagética religiosa, oferecendo uma alternativa à imensa maioria da documentação religiosa cartaginesa que vem de contexto funerário. Por outro lado, os reversos costumam ser interpretados enquanto emblemata, isto é, apontariam as riquezas locais. Um tipo de explicação que foi muito utlizado na interpretação da iconografia monetária da Grécia arcaica. No entanto, a recorrência dos motivos (cacho de uva; grão de trigo; atum) pode ter significados mais profundos: alianças políticas, religiosas ou econômicas. No que toca à epigrafia, o neo-púnico é corrente nas emissões mais antigas, enquanto o latim torna-se regra a partir das anexações romanas.

A região de Cirta, antigo coração massilo, e portanto, númida, parece ter se rendido à influência da colonização romana de Sittius, a partir de 46 a.C., mais precisamente à presença dos italianos. No entanto, peças anteriores, apesar de não poderem ser atribuídas com certeza a Cirta, possuem uma iconografia encontrada em cidades vizinhas, como Hippo Regius, que se aproxima dos tipos iconográficos númidas, notadamente a figura do cavalo a galope e dando passo. Além disso, há peças que trazem as imagens de Héracles, do atum, e do javali, iconografia também existente em Lixus, cidade de origem fenícia localizada no extremo ocidente da Berberia (Lixus).

Por outro lado, a imagem de Lívia, em algumas dessas cunhagens, tem seu papel redimencionado a partir da hipótese de essa figura ter sido reelaborada esteticamente de maneira a se enquadrar melhor na cultura religiosa local (Alexandropoulos 1987: 75). Este dado abre o precedente para a própria reanálise das imagens "tipicamente" romanas, tão freqüentes nas colônias e municípios, após a queda dos reinos númidas.

Por fim, uma interpretação clássica prega que as cunhagens citadinas, especialmente as pré-romanas, não representaram, em termos econômicos, uma efetiva inserção no mundo monetarizado da Antiguidade. Constituíram, de maneira análoga às cunhagens reais berberes, atos políticos de independência, já que somente estados autônomos e independentes emitiam numerário próprio (Mazard 1960: 115 . 116). Entendemos que os argumentos a favor dessa interpretação são fortes. Concentram-se na pobreza numérica das emissões e no metal utilizado (bronze na maioria das emissões, mas o chumbo é também documentado). No entanto, acreditamos que possam igualmente ser a prova de uma tentativa em bloco de preenchimento tanto do vácuo monetário deixado por Cartago, quanto das novas redes de alianças e associações que podem ter surgido então. É fato que, no que toca às cunhagens citadinas, mesmo sob o Império, a imensa maioria do numerário era de uso cotidiano, de troco, isto é, de baixo valor. No entanto, o conhecimento deste caráter local como dado de pesquisa é muito importante. A análise da iconografia e a sua contextualização devem levar em consideração o raio de ação dessas cunhagens, por mais restrito que tenha sido.

\section{Parte III - a cunhagem real}

\section{Dinastia masesila e massila: os númidas (incluindo a suposta dinastia getula) $^{9}$}

A cunhagem dos reis númidas é dividida entre as dinastias dos masesilos, dos massilos do oeste e dos massilos do leste. St. Gsell, há oitenta anos já havia compreendido o caráter desta cunhagem: "Toda essa cunhagem dos reinos masesilo e massilo está modelada a partir da de Cartago: o sistema metrológico parece ser o mesmo, o cavalo das moedas cartaginesas reaparece sobre as moedas númidas, as legendas são em púnico" (Gsell 1920, vol. IV: 158-159).

Veremos, no entanto, que a aproximação com a cunhagem cartaginesa é uma conclusão correta com relação às emissões númidas mais antigas: de Sífax e Vermina; de Massinissa e

(9) Parte das ponderações ora apresentadas aparecem em nosso artigo "O rei berbere e seu aparato iconográfico: o testemunho monetário”, em A linguagem das moedas: três leituras sobre iconografia numismática, $19^{\circ}$ Encontro Internacional Imagem e Ciência. CNRS - Centro Nacional de Pesquisas Científicas / França e Museu Paulista da Universidade de São Paulo, 2003, p. 33-58. 
seus sucessores, até Jugurta e Hiêmpsal II. Após o que, os elementos culturais e econômicos romanos passam a, gradativamente, prevalecer. Lembramos, no entanto, que as atribuições a muitos dos sucessores de Massinissa são feitas em razão de aproximações estilísticas com as peças de Massinissa, pois não possuímos legendas, mesmo abreviadas, com o nome desses reis - a escrita púnica das cunhagens berberes teve como regra abreviar os nomes dos reis, entrando no campo monetário a primeira e a última letra. J Mazard, que depois de L. Müller é o grande nome da numismática berbere, afirma que, tanto de maneira geral na Numismática, quanto especificamente com relação à cunhagem berbere que ele classificou, a atribuição tem que ser realizada através de cinco coordenadas: legenda; retrato; tipo e estilo; metal e peso; e epigrafia (Mazard 1957: 154-162).

\section{Sifax e Vermina}

A primeira cunhagem que nos propomos a analisar é a do rei masesilo Sífax e a de seu filho e sucessor, Vermina. O reino de Sífax é datado do final do século III a.C., mais exatamente do período quase inteiro da II ${ }^{a}$ Guerra Púnica (213-202 a.C.). Vermina, apesar de sofrer com os ataques massilos de Massinissa, teria reinado entre 202 e 192 a.C. As emissões atribuídas a esses dinastas são certas em razão das legendas que trazem, as quais nomeiam claramente esses reis.

As moedas de Sífax são de bronze, já as de Vermina são de prata. No entanto, as de Vermina trazem apenas um tipo monetário, sem variações, e do qual só conhecemos três peças. Com exceção destas três peças de prata, e uma pequena série, de estilo diferente, em prata e em ouro, que são atribuídas tradicionalmente a Jugurta e a Hiêmpsal II, desconhecemos moedas de metal nobre que possam ser atribuídas aos reis númidas antes do reino de Juba I (60-46 a.C.). O achado monetário de Constantina (antiga Cirta), que contém 237 peças de prata enterradas por volta de 79 a.C., só possuía moedas estrangeiras: atenienses, cartaginesas, marselhesas, espanholas e sobretudo romanas (Camps 1960: 206).
Conhecemos duas emissões de Sífax. J. Mazard dividiu ainda as duas séries por oficina. As do tipo 1 seriam de feitura local e as do tipo 2 teriam sido batidas em uma oficina espanhola (tipos 1 e 2). No entanto, não possuímos dados que possam efetivamente corroborar tal hipótese. Atualmente, de fato, a tendência é a de se atribuir a cunhagem do tipo 1 à oficina de Cirta (primeira capital de Sífax, portanto local das primeiras emissões) e a do tipo 2 à de Siga (segunda capital de Sífax) (Manfredi 1995: 307-308).

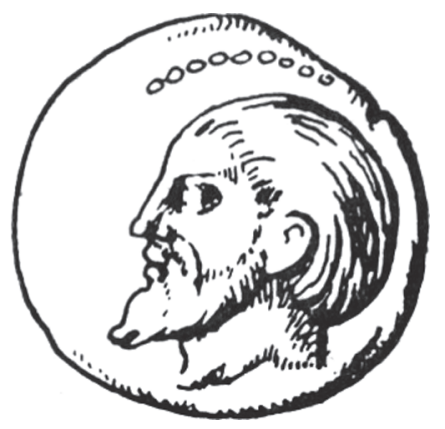

Tipo 1. Mazard (1955: 18 - tipo 2). (x 1,5)

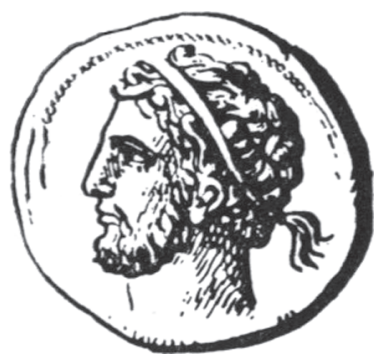

Tipo 2. Mazard (1955: 20 - tipo 10). (x 1,5)

As ruínas de Takembrit (Siga) apresentam poucos vestígios, a maioria de época romana. Em 1953, G. Vuillemot publicou um conjunto de cerâmicas de tradição púnica acompanhadas de uma moeda de Sífax (Vuillemot 1953, apud Camps 1960: 170). As moedas de Sifax encontradas em Siga são em número de seis: quatro estão no Museu de Oran. Em todas, o tema iconográfico é o mesmo: retrato do rei no anverso (tipos 1 e 2) e cavaleiro galopando no reverso (tipos 3 e 4). O anverso é normalmente interpretado como sendo o retrato do rei em razão da legenda, a qual aparece no reverso da moeda nomeando-o (Mazard 1955: 17; Krings 1995: 175). 


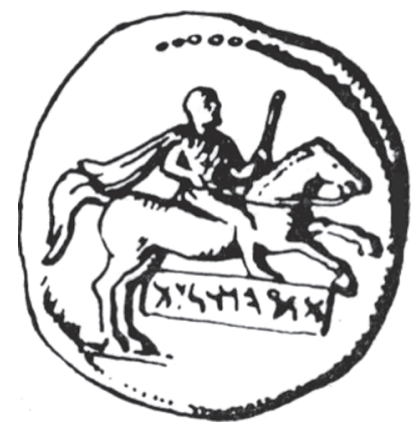

Tipo 3. Mazard (1955: 18 - tipo 1). (x 1,5)

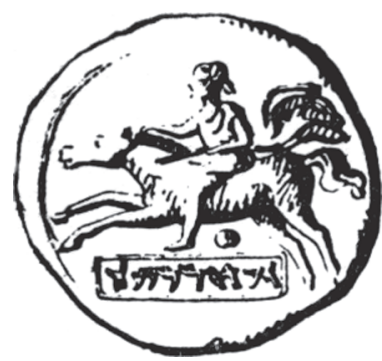

Tipo 4. Mazard (1955: 20 - tipo 10). (x 1,5)

Os detalhes da barba e do cabelo (diferentes de uma emissão para a outra), e principalmente, a inclusão do diadema ao tema iconográfico do tipo 2, levaram alguns autores a proporem estarmos lidando com dois personagens diferentes (Mazard 1955: 17). No entanto, a legenda é a mesma: SPhQ HMMLKT. A tradução que acreditamos ser mais correta é "Pessoa real de Sífax” (Mazard 1960: 157). Veremos que o termo HMMLKT, por inteiro, ou HT, abreviado, aparece também nas cunhagens dos reis massilos. Assim, a razão para dois retratos diferentes tem que ser outra.

As séries do tipo 1 são consideradas mais antigas. Ao elaborar seu catálogo, L. Müller, no final do século retrasado, dispunha de apenas um exemplar para cada tipo de anverso. Setenta anos mais tarde, J. Mazard pôde contar com um conjunto documental pouco maior. Ele trabalhou com doze exemplares do tipo 1. Em sua análise, o numismata verificou que tanto os anversos como os reversos destas doze moedas (particularmente os reversos) apresentavam pequenas variações, de modo que ele concluiu estarmos diante de uma cunhagem razoavelmente abundante. ${ }^{10} \mathrm{Na}$ opinião de J. Mazard, havia, por parte da autoridade emissora, um cuidado especial na elaboração destes retratos, daí as variações, mas a manutenção geral do tipo, dos traços do rosto, é constante em todas as doze peças, de modo que este autor acredita que este tipo estava calcado na realidade (Figs. 1, 1a, 1b). Com relação ao tipo 2, por outro lado, J. Mazard acredita que este represente a figuração idealizada do rei (Mazard 1955: 17). ${ }^{11}$

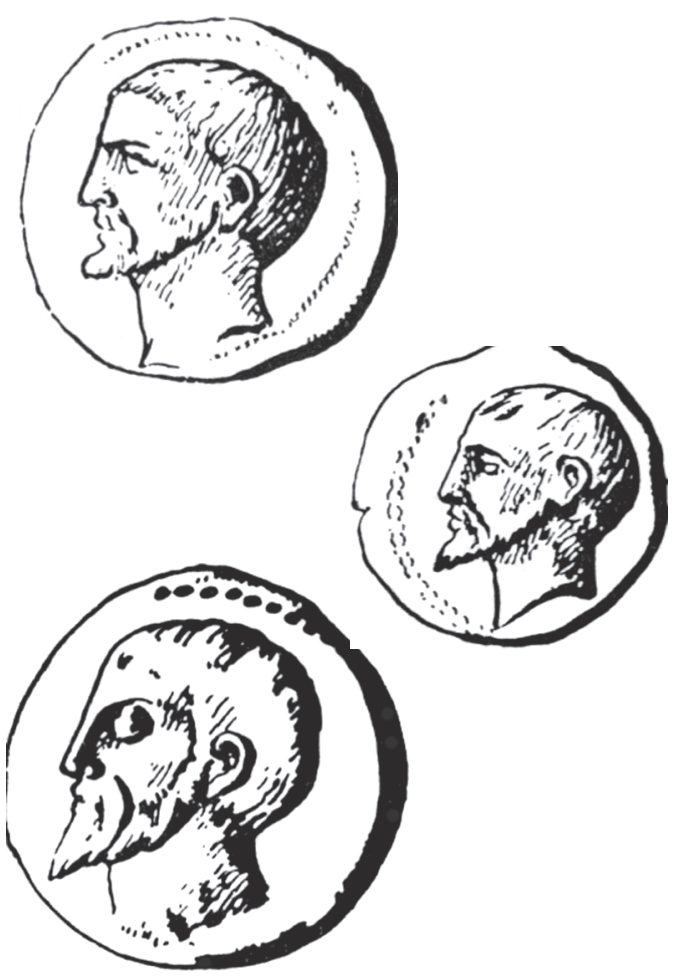

Figs. 1, 1a, 1b. Variações dos retratos de Sífax (anversos monetários). Mazard (1955: 18,19 - tipos 1, 3 e 6). $(\mathrm{x} 1,5)$

(10) As moedas na Antiguidade, de modo geral, eram cunhadas a martelo. Podemos afirmar que, em média, de 5 a 10 mil moedas eram produzidas por cada cunho de anverso, e de $30 \%$ a $50 \%$ a menos para cada cunho de reverso.

(11) O tipo 2 é composto por um retrato de homem com os cabelos ondulados e enfeitados por um diadema. G. Picard assinala que este tipo de penteado e o próprio diadema são atributos essenciais da composição imagética dos reis helenísticos (Picard 1983-1984: 77). 
Mencionamos acima como a cunhagem dos reis númidas é devedora do imaginário púnico. Este é um fato incontestável, como veremos na seqüência de nossa análise. No entanto, os anversos que acabamos de analisar representam justamente uma grande ruptura com esse imaginário. Acreditamos que a cunhagem emitida por Cartago, ao longo de $c$. trezentos anos, não comportou nenhum retrato realista ou idealizado de um de seus governantes. Este é, de maneira análoga à questão da realeza cartaginesa, um ponto sobre o qual os pesquisadores vêm debatendo já há algum tempo, pois uma série de moedas batidas na Península Ibérica pelos Barca (particularmente por Aníbal Barca), que trazem três cabeças masculinas no anverso (tipo imberbe coroado, tipo jovem sem coroa e com a maça de Héracles sobre o ombro, e tipo barbado e com a maça de Héracles sobre o ombro), ainda hoje não teve sua iconografia de anverso estabelecida de maneira absolutamente segura, de modo a satisfazer aos estudiosos como um todo. Há quem acredite termos um exemplo do alto grau de helenização de Cartago no final do século III a.C., quando esta permite, pela primeira vez em sua História, que comandantes militares gravem seus retratos nas moedas (Hamílcar apareceria no tipo barbado com coroa de louros e maça; Asdrúbal no tipo imberbe com coroa; e Aníbal no tipo jovem com maça e sem coroa). Contrariamente, apesar de não negar que o "império barca" na Espanha possuiu características tipicamente helenísticas, notadamente da propaganda política, outros pesquisadores tendem a ver nestes anversos a figura da divindade patrona de Tiro, Héracles-Melqart, e representações de Apolo, igualmente cultuado em Tiro. Ambas as divindades com cultos renovadamente fortalecidos durante o chamado período helenístico (Acquaro 1983-1984). A renovação dos contatos com o Oriente, mais marcadamente com a metrópole de Cartago, foi efetivada pelos Barca que ascendem ao poder em Cartago após a Ia Guerra Púnica.

A História política cartaginesa é ainda mal conhecida. No entanto, mesmo G. Picard, um defensor dos retratos, trabalha com o conceito de que os Barca não criaram um reino helenístico independente de Cartago na Península Ibérica (1983-1984: 75-76). Ainda assim, este autor sustenta que estes empreenderam uma política de inserção na sociedade local (casando-se com filhas da nobreza ibera, por exemplo) com o intuito de tornarem-se "pessoas reais", o que teriam conseguido. Desse modo, visando fortalecer suas imagens entre os povos sobre os quais sustentavam seu poder militar, e mesmo entre os gregos e romanos, teriam gravado seus retratos seguindo as regras da propaganda política helenística (utilizando a iconografia de Héracles). No entanto, Picard não explica porque apenas um dos retratos, do tipo imberbe, aparece coroado.

A iconografia monetária dos Barca ainda aguarda uma análise definitiva. No entanto, não acreditamos que as imagens que ali aparecem sejam retratos helenísticos. Aníbal ao invadir a Itália pelo sul (no final do século III a.C.), cunha diversas séries monetárias que são postas em circulação localmente (na verdade temos representado nestas séries o esforço monetário máximo de Aníbal). Estas possuem a tradicional iconografia cartaginesa (cabeça de Core, no anverso, e cavalo, nas mais diferentes posições, no reverso) (Jenkins 1987). Desse modo, a solução sobre a iconografia monetária barcida espanhola deve ser procurada na própria Península Ibérica. ${ }^{12}$

F. Coarelli e Y. Thébert elaboraram um detalhado estudo sobre a grande arquitetura funerária berbere, majoritariamente númida, no qual defendem a tese de que o Norte da África participou das correntes culturais, comerciais e migratórias do mundo mediterrânico desde o Neolítico, e que situá-la nessa corrente polimorfa, mas fundamentalmente unitária, é perceber que este território não foi um setor atrasado, incapaz de acompanhar as inovações econômicas, técnicas e culturais que vinham moldando o Mediterrâneo há milênios, e cujos

(12) Um renomado numismata espanhol, L. Villaronga, realizou uma análise específica destas moedas e, em sua opinião, elas representam diferentes imagens do Héracles de Gades, antiga colônia fenícia localizada no extremo oposto de Lixus (Villaronga 1973, apud Picard 1983-1984: 76-77). 
impulsos vinham, freqüentemente do Oriente Próximo (Coarelli \& Thébert 1988: 770).

Acreditamos que, em termos teóricos e enquanto instrumento de pesquisa, esta tese não apresenta problemas. No entanto, salientamos que com relação a certos aspectos, por exemplo, a organização política da sociedade berbere, a teoria da longa duração nos parece mais produtiva do que a simples sobreposição de um modelo real helenístico a esta sociedade. Os grandes monumentos funerários berberes se enquadram na tese apresentada acima, pois possuem elementos, entre outros - inclusive autóctones -, mediterrânicos ocidentais (os grandes montículos do Rharb, por exemplo), e helenísticos (Medracen). Entretanto, a organização espacial, e sua arquitetura, na Berberia, nos períodos proto-histórico, cartaginês e helenístico ainda é hoje pouco pesquisada. Sabemos que cidades de pequeno porte como Tamuda, e outras maiores, como Volubilis, aliaram soluções estrangeiras a locais, separando o mundo doméstico e privado do público e oficial. Os reinos centralizados do século III a.C. possuem diversos aspectos inovadores: a presença do rei nas cidades, denominadas de "capitais" pelas fontes escritas gregas e latinas, e a emissão de numerário próprio são os principais. Não obstante, o culto ao rei possui raízes berberes (os próprios monumentos funerários proto-históricos, de arquitetura diversa das tumbas e mausoléus dos séculos III e II a.C.), da mesma maneira que a essência do poder real, ligada inexoravelmente à força guerreira do chefe (Kormikiari 2000: 117-188).

Afirmamos anteriormente que as cunhagens reais e citadinas surgem no vácuo criado pela destruição de Cartago. Neste contexto, apesar de poderem ser consideradas incipientes e de circulação local, o Norte da África, que antes praticamente desconhecia o metal cunhado que não fosse cartaginês - e mesmo este circulou pouco ali -, ingressa em um período de exacerbada atividade monetária (mesmo levando em consideração o que colocamos acima com respeito às cunhagens citadinas e seu caráter primordial de afirmação institucional, enquanto entidades políticas autônomas, e igualmente tendo em mente que a troca de produtos persistiu). $\mathrm{O}$ fato de os reis berberes não terem cunhado em metal nobre e de terem tido uma cunhagem pequena em quantidade, comparando-se com sociedades helenísticas, aliado à tese da longa duração, levou G. Camps a afirmar que paralelamente à monetarização da sociedade berbere, as trocas entre produtos continuaram a ser um aspecto essencial da vida econômica e social da Berberia. De fato, a medida do trigo ou da cevada, ou então a cabeça do gado, foram, até recentemente, produtos com valor monetário aceitos, no interior, tão facilmente quanto a moeda. Em 1953, G. Camps relata ter presenciado, na região de Babors, manteiga derretida sendo paga em trigo. Essas trocas eram correntes e existia um sistema de equivalências estabelecido, conforme a época do ano, e que era aceito por todos. Este pesquisador acredita ser muito provável que os impostos solicitados pelo rei na Antiguidade fossem pagos em produtos, em trigo ou em gado. Os recenseamentos anuais dos cavalos, dos quais Estrabão fala (XVII, 3, 19), permitiriam um certo controle dos recursos dos súditos númidas (Camps 1960: 209).

Neste contexto, a cunhagem real faz uso de uma arma propagandística absolutamente disseminada pelo mundo mediterrânico então. O retrato do rei nas cunhagens foi utilizado, em nossa opinião, como um diferenciador e um meio de afirmação política por parte dos reis berberes, todos eles. Assim, o próprio contexto geral, africano e mediterrânico, influenciou essa solução. Não precisamos depender da existência de uma cunhagem com retratos reais em Cartago para poder interpretar os retratos dos berberes. O historiador da Arte, J. J. Politt (1986:11) sustenta que as mudanças políticas que ocorrem durante o período de Alexandre III da Macedônia na bacia mediterrânica oriental levam a profundas mudanças culturais (obsessão pela riqueza; mentalidade teatral, mentalidade acadêmica, individualismo e visão cosmopolita). O mais claro desenvolvimento da visão individualista é percebido na arte do retrato. Escultores helenísticos de retratos produzem os mais belos exemplares de obras nos quais o caráter 
pessoal, o temperamento, a natureza do indivíduo aparecem. Ao mesmo tempo, as artes visuais tornam-se um dos principais meios através dos quais os governantes incitavam a população a respeitá-los e a aceitá-los. Sua ação política e suas conquistas (tanto pessoais quanto as que beneficiavam diretamente o povo) eram ali propagadas.

Alexandre é o precursor desse tipo de propaganda individual e será seguido pelos seus sucessores. O próprio Império Romano herda as tradições helenísticas ligadas à imagem de Alexandre e vários são os imperadores que utilizam os atributos e a construção iconográfica de sua propaganda.

Entretanto, apesar de ter sido o protótipo relembrado em momentos mais conturbados de afirmação política, a imagem de Alexandre não poderia se manter indefinidamente em um mundo que, após a sua morte, vai se reestruturar politicamente com a divisão do império helenístico pelos seus generais. Assim, o retrato real ganha em sofisticação e o individualismo prevalece; surgem as representações dos diferentes reis (tanto em retratos monetários quanto em outros suportes como esculturas) e surge também a criação de monumentos comemorando o que o rei havia feito ou construído. Assim temos cenas de batalhas, cenas de caças, procissões militares ou religiosas. Nessas imagens as qualidades do rei eram destacadas: sua coragem, piedade, destreza, entre outras. $\mathrm{O}$ mundo helenístico, no que toca à representação das imagens reais nas moedas, vai centrar forças na reprodução individualizada do rei (por vezes irreal, pois era ditada por questões propagandísticas). A importância política dessa representação centrava-se no fato de que, devido às grandes extensões de alguns dos reinos helenísticos, não era raro que um determinado rei não fosse fisicamente conhecido por todo seu povo, o retrato monetário supria essa falta.

$\mathrm{O}$ rei berbere não possuiu o poder de um monarca helenístico, mas acreditamos que utilizou a gravação de seu retrato nas moedas, inclusive o idealizado, à luz dos pontos apresentados acima.

Não obstante tudo o que falamos a respeito do retrato real berbere, o cavaleiro galopando que aparece nos reversos das moedas de Sífax (tipos 3 e 4) é, em nossa opinião e em termos propagandísticos, a composição iconográfica da cunhagem desse rei que mais impacto causa, a qual abre o precedente para as emissões dos próximos reis berberes, seja do masesilo Vermina, seja dos dinastas massilos.

Para interpretá-la faremos uso de uma documentação material posterior. Uma estela anepígrafa em alto-relevo, descoberta na Tunísia (Berberia Oriental), nas proximidades da cidade de Chemtou (antiga Smitthus) e datada de c. 50 . 46 a.C., mostra um personagem a cavalo, um númida, marchando à direita. A importância da cavalaria númida na Antiguidade, entre o período cartaginês, dos reinos númidas, e romano, foi minuciosamente detalhada por St. Gsell (1927, vol. V: 181-186). O pesquisador, que publicou pela primeira vez esta estela, acredita que estejamos frente a uma rara figuração do cavaleiro númida (Bertrandy 1986: 58).

A estela de arenito encontra-se bem conservada, o que facilita sua análise. $\mathrm{O}$ cavaleiro aparece representado de $3 / 4$, possui abundante cabeleira, disposta em penteado típico númida (cachos ondulados) (Estrabão (II, 3, 7), Sílio Itálico (Punica III, 284, apud Bertrandy 1986: 58, nota 4). O personagem carrega ainda um diadema que lhe cai na fronte e nas orelhas. Sua barba espessa é igualmente ondulada (como o é a barba do retrato do tipo 2 de Sífax), veste uma túnica curta, com mangas compridas. Sobre esta está jogado um manto, pregado ao ombro por uma fíbula redonda. O manto cobre o cavalo. A perna direita do cavaleiro está nua. Ele veste um tamanco com sola trançada, o qual, segundo Bertrandy, é um apetrecho não habitualmente usado por um númida (idem). A mão esquerda mantém as rédeas bem elevadas, ao mesmo tempo em que agarra a crina do cavalo. $\mathrm{Na}$ opinião do pesquisador, as feições do rosto do personagem exprimem segurança e firmeza (Bertrandy 1986: 60). Por fim, à direita desta cena, dando uma ilusão de perspectiva, aparece figurada um palmeira com sete folhas.

Representações de cavaleiros númidas, como 
já mencionado, são raras. Um dos poucos exemplos que possuímos é um medalhão de terracota (Fig. 2) encontrado em Cartago, cuja representação ainda não foi definitivamente definida (divindade-cavaleiro?). O personagem, portando um escudo e uma longa lança (de maneira análoga a algumas variantes dos reversos de Sífax), cavalga sem sela e segura rédeas presas a um freio. Este documento possui uma datação alta: século VI ou IV a.C. De maneira análoga, uma estela do Museu de Alger tem como tipo iconográfico principal um cavaleiro representado de frente, com rosto redondo e barba pontuda (desta vez a relação pode ser feita com a forma da barba do tipo 1 de Sífax, mas também, como veremos adiante, com a de outros reis númidas). Este cavaleiro cavalga sem sela mas também sem rédeas e freios. Carrega em sua mão um escudo e três lanças, aos pés dele aparece uma avestruz (caçador?). Esta estela é datada do século II a.C. (Bertrandy 1986: 60-61).

Ainda uma pequena placa de terracota, pintada, traz a representação de um cavaleiro atingido nas costas por uma flecha. Ele está jogado sobre seu cavalo, que foge a galope (Fig. 3). $\mathrm{O}$ cavalo não possui qualquer tipo de arreios ou rédeas. Esta peça foi encontrada no sítio de Canosa (antiga Canusium), nas proximidades de
Cannes, Itália. É datada do final do século III a.C.. Na opinião de A. Bertrandy, a cabeleira espessa e ondulada, presa por um diadema, a barba pontuda do cavaleiro e o fato de o cavalo estar sendo montado sem arreios, permitem que qualifiquemos o personagem como um númida. Mas um chefe númida, e não um simples cavaleiro (idem: 64)

Por fim, um último testemunho dos cavalei-

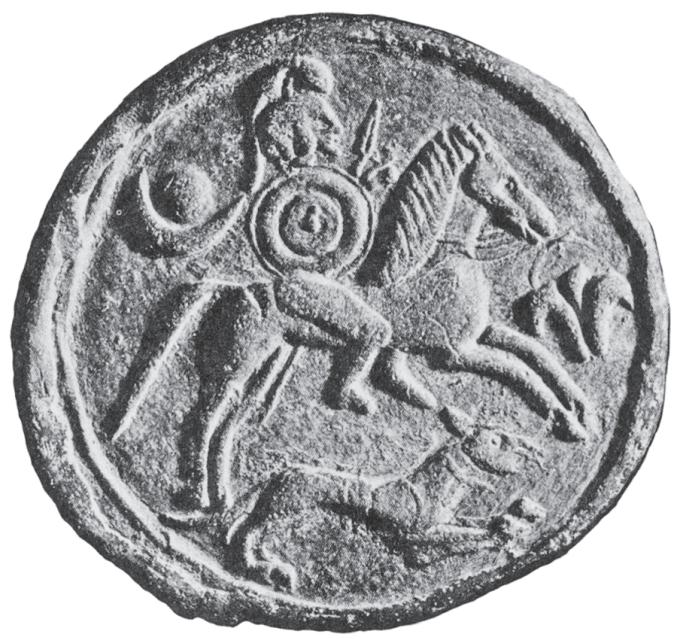

Fig. 2. Cartago (necrópole de Douïmès): medalhão em argila cozida representando um cavaleiro com armas e com um cachorro (séc. VI a.C.). Decret (1977: 217).

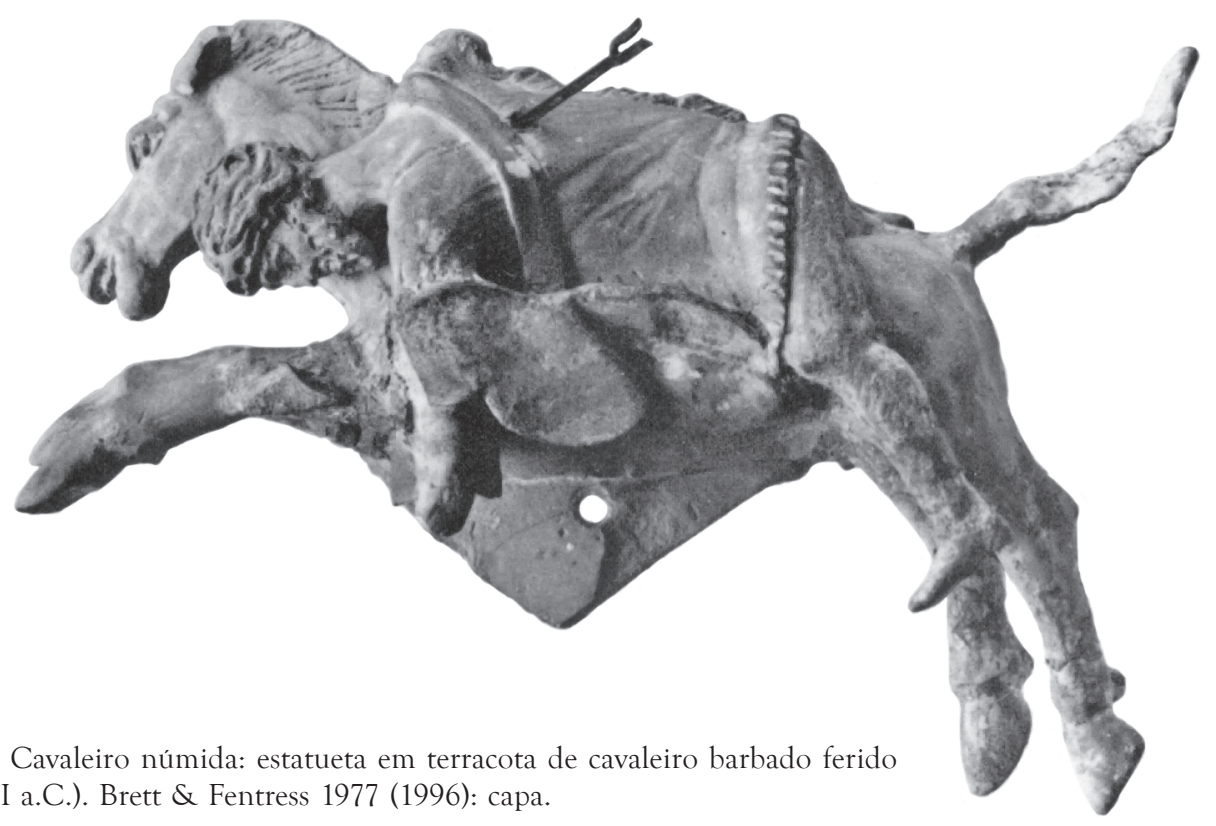

(séc. III a.C.). Brett \& Fentress 1977 (1996): capa. 
ros africanos é a figuração da cavalaria moura na Coluna de Trajano, datada do século II d.C.. Aqui novamente, e séculos depois dos exemplos apresentados, vemos as mesmas características já assinaladas: cabeleira em cachos ondulados e cavaleiros montando seus cavalos sem os apetrechos de contenção do animal (as pernas o seguram). Uma diferença marcante entre este quadro e o da estela de Chemtou é o fato de estes cavaleiros mouros estarem todos descalços (Bertrandy 1986: 65).

Os autores gregos e latinos (Tito-Lívio XXIX, 34, 5; Apiano, Lib, 71; Estrabão, XLVIII, 3, 7; Sílio Itálico, I, 215-217) assinalam inúmeras vezes a maneira tradicional berbere de montar um cavalo: livremente, sem arreios, freios ou rédeas.

Em seu levantamento iconográfico, A. Bertrandy (1986: 67) encontrou algumas imagens de cavaleiros montando animais selados, e com arreios (à moda romana, com o ephippium). No entanto, estas estelas, representando tanto estrangeiros habitando o Norte da África, como o uso, por parte dos indígenas, do modo romano de cavalgar, são todas datadas dos séculos I e II d.C..

A. Bertrandy conclui que o uso de sela e arreios torna-se comum no Norte da África apenas durante o Império Romano. A partir das placas de terracota encontradas na Itália, este autor propôs, então, que somente ao chefe númida era outorgado o direito de cavalgar um animal com os apetrechos de contenção e direcionamento. No que toca à estela de Chemtou, Bertrandy acredita estar ali representada a figura do rei númida Juba I. Apesar de entender que se trata de uma atribuição incerta, pois não há nenhum tipo de inscrição sobre a peça, este autor faz comparações com esculturas conhecidas de Juba I (Bertrandy 1986: 70).

Com relação aos reversos de Sífax, os quais, como vimos, apresentam um cavaleiro galopando, com ou sem arreios, e carregando uma vara para melhor conduzir o animal, ou então, uma longa lança, podemos interpretar essa imagem à luz do que foi exposto acima, e igualmente baseando-nos no caráter de chefe guerreiro que, acreditamos, foi um dos pilares de sustentação do rei berbere.

Assim, Sifax anuncia em seus reversos que ele era um rei, como a própria legenda afirma (ela está colocada no reverso e não no anverso, de maneira análoga a cunhagens dos reis helenísticos orientais). Mas era um rei guerreiro, um cavaleiro.

Esta propaganda, em nosso entender, servia tanto para os chefes menores (e para os próprios súditos), como para as comunidades libifenícias da região costeira de Siga, e aquelas de Cirta.

Neste momento a cunhagem de Sífax é a única não cartaginesa da Berberia. Este dado por si só demonstra que a ascensão dos chefes berberes locais estava se consolidando, ao mesmo tempo em que um imaginário próprio já começava a se formar.

As moedas de Vermina (=Verminad), seu filho, também feitas com cuidado, mostram o jovem rei imberbe e diademado (tipo 5), no anverso, ${ }^{13}$ e um cavalo livre galopando (tipo 6), no reverso. As moedas deste rei masesilo seriam contemporâneas à segunda emissão de Sífax (Camps 1960: 189)..$^{14}$ Vermina reina em condições obscuras e precárias, por poucos anos. St. Gsell propôs que pai e filho haviam se associado no final do reino de Sífax, baseado no anverso das moedas de Vermina. O rosto imberbe demonstraria juventude. Todos os retratos dos primeiros reis númidas que possuímos são rostos com barba (Gsell 1927, vol.V: 125).

O tipo iconográfico do cavalo aparece nas cunhagens seguintes, dos reis massilos. Trataremos todas essas imagens em conjunto, pois acreditamos que possam ser interpretadas à luz de uma mesma contextualização.

(13) J. Mazard identificou três retratos diferentes, mas todos são rostos jovens, imberbes, com cabelos curtos presos por um diadema. É possível visualizar o manto drapeado em seu colo. Este tipo de retrato não aparece na cunhagem republicana da época.

(14) Este autor propõe que a cunhagem de Vermina tenha sido batida enquanto este comandava os exércitos de Sífax, então prisioneiro dos romanos (Camps 1960:190). 


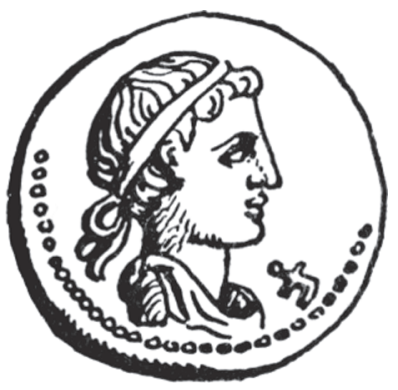

Tipo 5. Mazard (1955: 21 - tipo 13). (x 1,5)

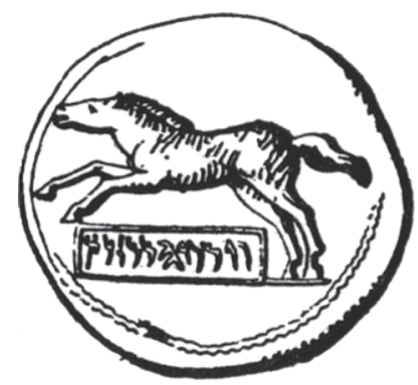

Tipo 6. Mazard (1955: 21 - tipo 14). (x 1,5)

\section{Massinissa e seus sucessores}

A atribuição de numerário próprio aos sucessores de Massinissa, os quais conhecemos pelas fontes textuais e epigráficas, é baseada apenas nas legendas abreviadas de reverso. Alguns dos exemplares são classificados por Mazard como RRR, isto é, extremamente raros.

Os tipos iconográficos, em termos de conteúdo, são basicamente os mesmos, tanto para Massinissa quanto para seus sucessores: retrato barbado, laureado ou diademado, e cavalo dando passo, ou galopando livre (tipos 7 a 15).

As moedas ora analisadas podem ser divididas em dois grupos, um com cabeça laureada e legenda MSNSN HMMLKT (tipo 7) e outro com cabeça diademada (tipo 10) e laureada (tipo 11) e legendas abreviadas. As moedas do primeiro grupo possuem uma metrologia, um peso, que as aproxima dos últimos bronzes púnicos discutidos no início deste artigo. Por outro lado, as peças com cabeça diademada, posteriores, têm peso menor. Na opinião de J. Alexandropoulos,

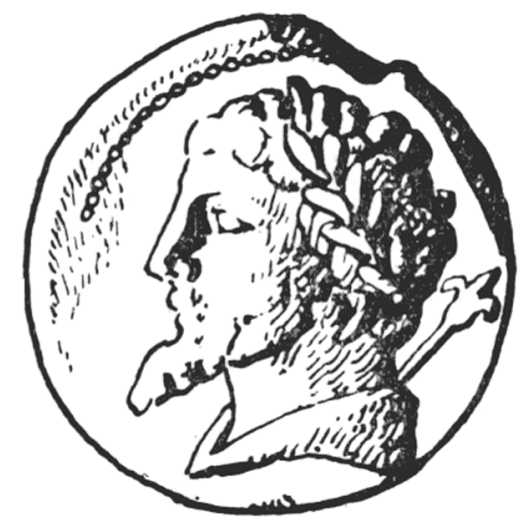

Tipo 7. Mazard (1995: 30 - tipo 18). (x 1,5)

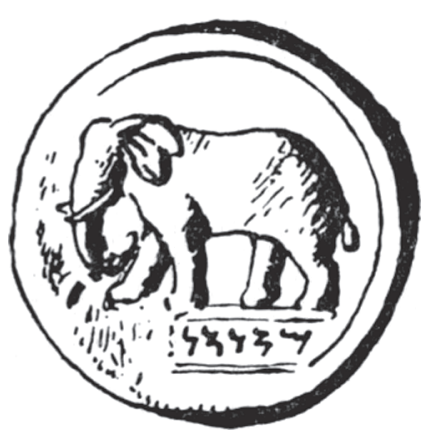

Tipo 8. Mazard (1995: 30 - tipo 17). (x 1,5)

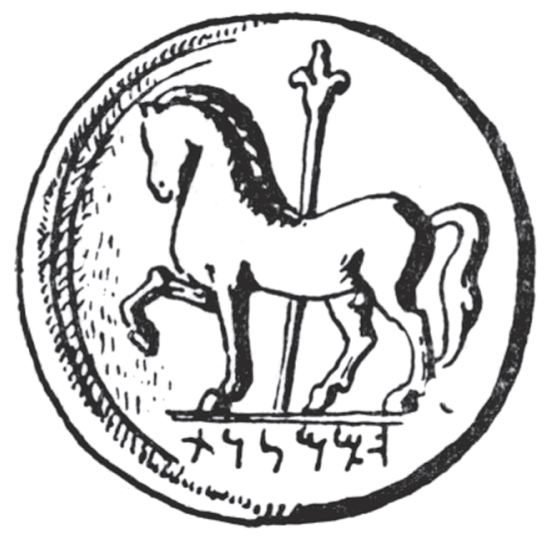

Tipo 9. Mazard (1995: 30 - tipo 18). (x 1,5) 


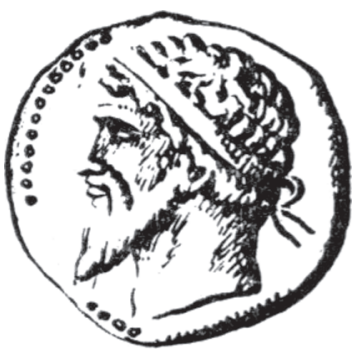

Tipo 10. Mazard (1995: 40 - tipo 57). (x 1,5)

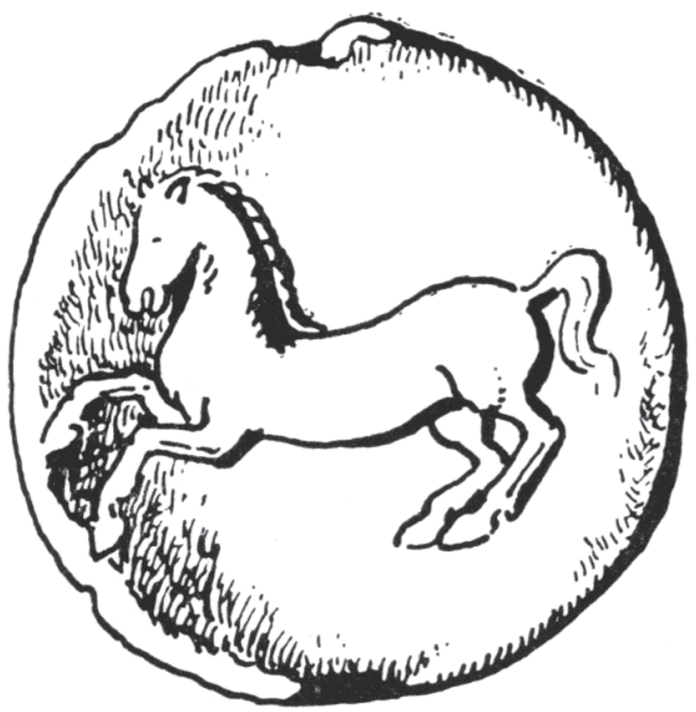

Tipo 12. Mazard (1995: 36 - tipo 42). (x 1,5)

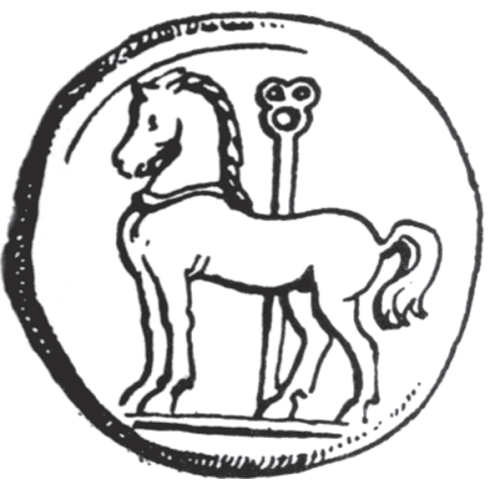

Tipo 14. Mazard (1995: 37 - tipo 44). (x 1,5)

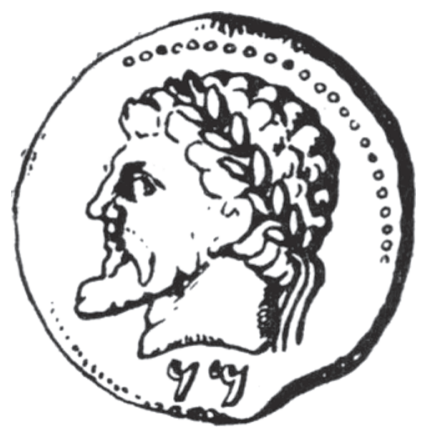

Tipo 11. Mazard (1995: 31 - tipo 19). (x 1,5)

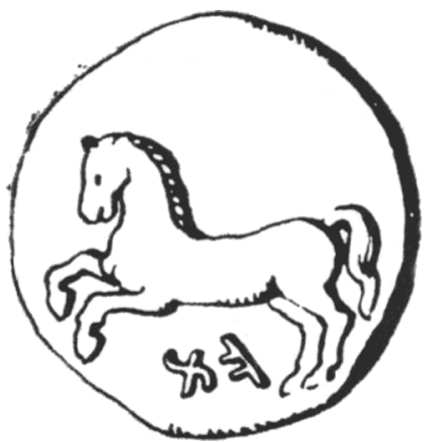

Tipo 13. Mazard (1995: 31 - tipo 19). (x 1,5)

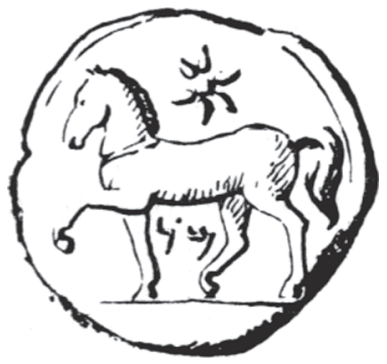

Tipo 15. Mazard (1995: 40 - tipo 57). (x 1,5) 
estamos diante de duas emissões distintas. $\mathrm{O}$ numerário com cabeça laureada é o mais antigo e foi cunhado a partir dos bronzes cartaginesas de 100 e $20 \mathrm{~g}$. Já as séries com cabeça diademada são representadas por duas denominações. Provavelmente seguiam a metrologia das emissões barca da Península Ibérica, a qual seguia um padrão 10-12 g, e compreendia uma unidade e uma meia-unidade (Alexandropoulos 1989: 538). ${ }^{15}$

No que concerne aos retratos, o tipo laureado (tipo 7) é atribuído apenas a Massinissa, quando a legenda do reverso é bem específica: MSNSN HMMLKT. De maneira análoga à legenda de Sífax, a tradução aqui é "Pessoa real de Massinissa". Já os tipos anepígrafos, e com legenda bilateral, são normalmente atribuídos aos sucessores imediatos de Massinissa. Estas legendas bilaterais são sempre abreviações do nome de Massinissa ou Micipsa - MN (por vezes a legenda $\mathrm{MN}$ aparece sozinha nas moedas, inclusive na do grupo 2, da cabeça diademada. Então, a atribuição é feita apenas para Massinissa); do termo pessoa real - HT; dos sucessores Gulussa ou Gauda (Gulussan e Gaudan em púnico)- GN e Aderbal - AL. Devido ao mau estado de conservação das peças, J. Mazard conseguiu ler apenas estes nomes. É possível que os outros sucessores tenham numerário próprio entre as séries que possuímos. Em termos de variação de cunho, a quantidade é muito grande, de modo que, apesar de ainda termos que considerar essa cunhagem massila dos primeiros tempos como incipiente, um esforço grande em emitir numerário próprio foi mobilizado. Por fim, a legenda $\mathrm{H}$ (he neo-púnico), sozinha, é utilizada como única base para a atribuição de numerário específico a Jugurta e a Hiêmpsal.

(15) Massinissa emite apenas em bronze e chumbo, por vezes coberto com cobre. As peças em chumbo são todas posteriores aos bronzes legendados. Apesar do péssimo estado de conservação parecem portar sempre a legenda MN (Massinissa). A raridade de ligação de cunho (que avalia a quantidade de cunhos utilizados em uma emissão, e, conseqüentemente, o número de peças produzidas) leva à crença de que a emissão desse numerário tenha sido considerável (Gerin 1989: 510).
Em um primeiro momento, a primeira efígie destas séries (tipo 7), que aparece laureada e cuja emissão é atribuída apenas a Massinissa, era tida como o retrato de Massinissa, o qual foi transformado em um retrato padrão, tradicional. Teria sido usado por seus sucessores de maneira análoga às primeiras emissões dos diádocos helenísticos, que bateram suas primeiras moedas utilizando o retrato de Alexandre, o grande (Mazard 1957: 157).

No entanto, esta interpretação foi modificada a partir de análises realizadas nos conteúdos de alguns achados monetários contendo moedas númidas dos tipos ora estudados. Assim, M. Troussel (1948, apud Camps 1960: 44), relatando uma notícia dos arredores de Constantina, em Tiddis, ${ }^{16}$ verifica a existência de mais de 25 retratos com feições diferentes, e G. Thomas (1949, apud Mazard 1957: 157 nota 2), também analisando um achado monetário de Constantina (com mais de 2 mil peças númidas - IGCH 2304), identifica mais de dez retratos em seu lote. Em suma, apesar de o retrato laureado e diademado apresentar uma composição geral homogênea (cabelos curtos e ondulados, barba pontuda) podemos identificar, mais uma vez, uma analogia com as peças de Sífax, isto é, uma possível preocupação com a representação realista.

A questão dos atributos destes retratos é outro ponto que merece uma breve argumentação. A primeira e mais imediata explicação para o diadema, originariamente símbolo real persa, é, enquanto marca do poder real, imagem que vemos no tipo divinizado de Alexandre com os cabelos presos pelo diadema, usado na cunhagem de Demétrio Poliorcetes (Jenkins 1972: 215, n. 518). Já na cunhagem dos Barca,

(16) Tiddis é uma localidade nos arredores de Constantina (antiga Cirta), na qual foram encontrados importantes documentos berberes, notadamente vasos cerâmicos e moedas de Massinissa e seus sucessores. A área ao redor desta antiga aldeia massila (onde coabitavam, provavelmente, vários grupos númidas além dos massilos) é rica em bazinas (grandes estruturas funerárias circulares protohistóricas, tidas como sepulturas de chefes berberes) (Camps 1960: 43, 144). 
mencionada acima, a figura barbada carrega nos cabelos uma coroa de louros, símbolo da vitória. Como complemento destes atributos reais, podemos mencionar os cetros que aparecem tanto no anverso como no reverso destas moedas númidas. Acreditamos que a escolha de denominações estrangeiras, como as que aparecem nas legendas, é entendida por nós enquanto manipulação e apropriação de um ideário que, mesmo não condizente com a realidade da realeza berbere, serviu como meio de auto-afirmação tanto frente os chefes menores quanto frente os estrangeiros. $\mathrm{O}$ mesmo tipo de raciocínio seguimos com relação a esses símbolos iconográficos.

O tipo do cavalo, no reverso destas moedas, no entanto, é o que mais nos interessa. Acreditamos que não apenas os númidas copiaram o tipo monetário cartaginês mais tradicional, como igualmente se apoderaram do seu imaginário, cuidadosamente criado por Cartago ao longo de sua História, como pretendemos mostrar a seguir. Desse modo, abrimos um parêntese para apresentar uma análise do cavalo nas moedas cartaginesas. Em seguida, retomamos os númidas.

Um simples folhear de qualquer catálogo de moedas cartaginesas é suficiente para verificarmos que o motivo iconográfico do cavalo, juntamente com a palmeira e a cabeça feminina (na maioria das vezes lida como CoreTanit), é a imagem mais utilizada na cunhagem púnica ao longo de toda sua história monetária, isto é, do final do século $\mathrm{V}$ a.C., quando inicia sua cunhagem, até a sua destruição final, em 146 a.C.. Ao contrário da palmeira e da deusa, no entanto, o cavalo aparece sempre como tipo principal do reverso.

Sinteticamente expondo, o cavalo é representado de variadas formas: por inteiro, onde pode estar parado, galopando, empinando, com a cabeça voltada para trás, e/ou dando um passo com uma das patas dianteiras; ou apenas a cabeça/prótomo do animal, neste caso, na maioria das vezes, dentro da mesma concepção estética que rege a representação das cabeças humanas (Figs. 4, 5, 6).

De uma maneira geral, e em conseqüência do problema metodológico de se analisar uma documentação com origem oriental unicamente a partir de dados greco-latinos, a interpretação mais comum desta imagem utiliza, como base de estudo, o relato lendário da escolha do terreno para a fundação de Cartago, que nos foi apresentada pela historiografia greco-latina. Justino (XVIII, V, 15-16) é a fonte textual que registra o relato mais completo: "Ao se cavar, então, nos fala ele, encontramos uma cabeça de boi; foi um presságio de terra fértil, mas de uma cidade trabalhadora e sem descanso de escravos. Assim, eles levam a cidade para um outro local. Lá, fazemos também uma descoberta, a de uma cabeça de cavalo, significando um povo guerreiro e poderoso: sobre esse auspício a cidade foi fundada" (tradução nossa do francês).

A partir da idéia de poder e beligerância trazida pela imagem do cavalo, que o texto revela, acreditou-se, então, que este animal havia sido escolhido como símbolo da cidade e por isso teria sido tão empregado na iconografia monetária (Jenkins \& Lewis 1963: 12).

Apesar de esta interpretação ser defendida por pesquisadores tão conceituados quanto Kenneth Jenkins, ela vai contra nossa proposta de análise geral da civilização púnica (Kormikiari 2000: 326). Mais uma vez não se trata de, forçosamente, passarmos a dar valor apenas ao dado oriental, mas sim, de procurar nas fontes, não esquecendo as semíticas, pistas que possam apontar novos caminhos ou confirmar os já traçados e aceitos. O numismata Jean Bayet, em seu artigo "L'Omen du cheval" (1941), procura demonstrar o caminho inverso. Isto é, os relatos greco-latinos teriam se inspirado na imagística monetária púnica para incluir na descrição da lenda de fundação a cabeça de cavalo significando força guerreira.

Seu estudo é feito a partir da análise iconográfica das moedas púnicas que trazem como figura de reverso o cavalo, e também com base em um trecho da Eneida de Virgílio (441-445) no qual uma determinada frase caput acris equi - é interpretada por ele como “cavalo prestes a morder" (Bayet 1941: 176). Bayet faz menção especial aos desenhos das cabeças de cavalo, que aparecem especialmente em algumas das emissões dos tetradracmas, e 


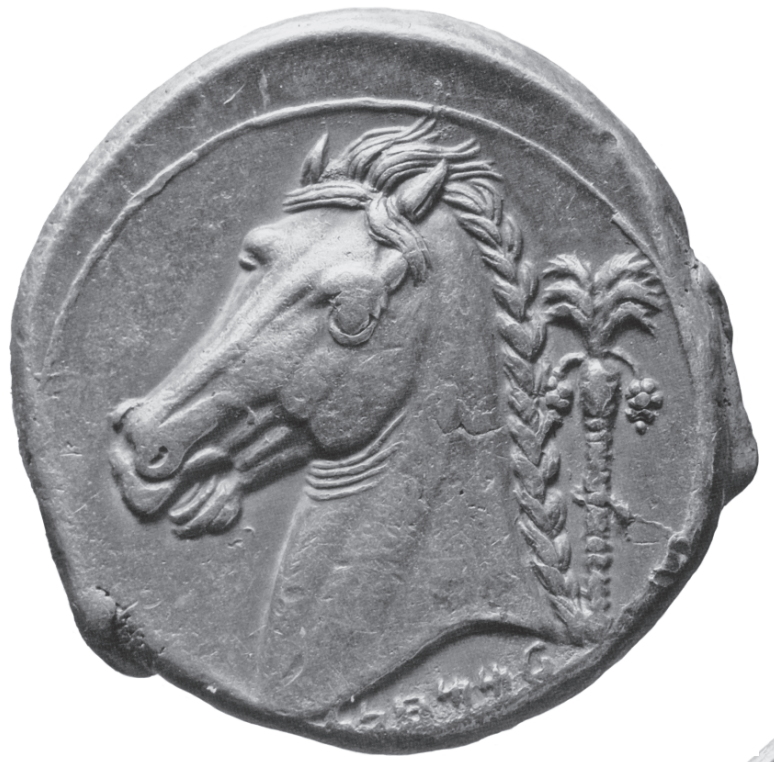

Fig. 4. Oficina da Sicília (320-306 a.C.), reverso, tetradracma, prata. Manfredi (1995: prancha 21).

Fig. 5. Oficina da Sicília (350-340 a.C.), reverso, tetradracma, prata. Manfredi (1995: prancha 17).

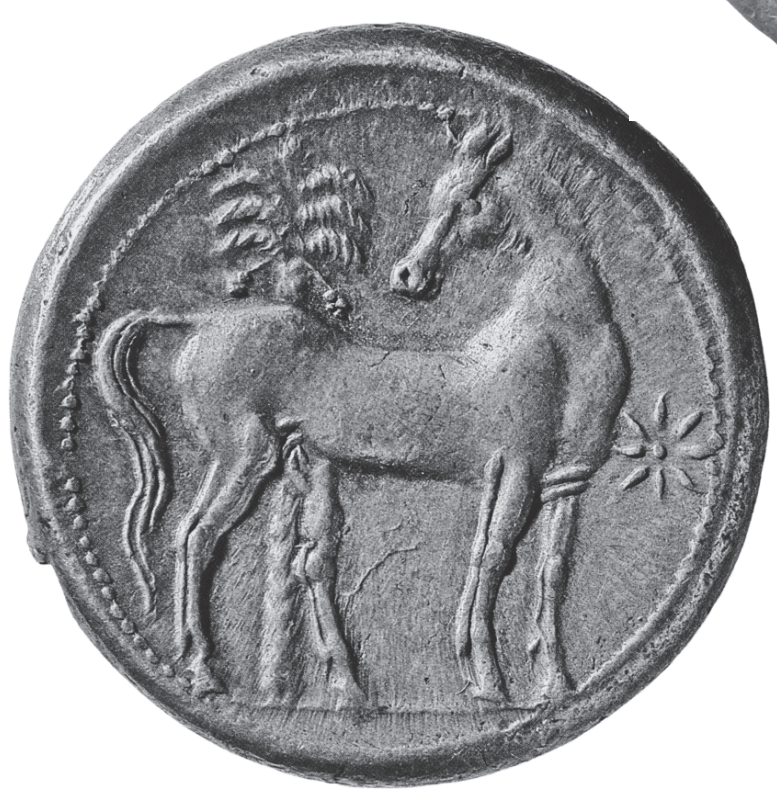

Fig. 6. Oficina de Cartago (séc. III a.C.), reverso, didracma, prata. Manfredi (1995: prancha 7). 
que mostram o animal em "movimento", prestes a morder (Fig. 4). Esta mesma ação é igualmente detectada desde os primeiros bronzes púnicos anepígrafos, datados da metade do século IV a.C., que têm como figura de reverso cavalos livres, ou seja, sem arreios, empinando ou galopando. Por outro lado, as moedas cunhadas nas oficinas de Cartago trazem sempre o cavalo por inteiro (jamais apenas a cabeça) e quase nunca em movimento. No entanto, quando novamente o fazem vemos o cavalo em posição ameaçadora, como nas peças em que ele, por inteiro, aparece com a cabeça voltada para trás, muitas vezes dando um passo, como se estivesse pronto a atacar (Fig. 6).

Se analisarmos as oficinas de cunhagem das peças acima mencionadas, veremos que a maioria foi emitida na Sicília, inseridas no contexto de disputa territorial e destinadas à paga dos mercenários dos exércitos cartagineses. Seria valendo-se delas - primeiras moedas batidas por Cartago - que a figura do cavalo, como tipo monetário púnico, adquire seu significado.

Particularmente os retratos dos cavalos em algumas destas moedas, sempre em $3 / 4$ de perfil e em movimento - arreganhando os dentes -, só tiveram sua execução possível a partir da transformação nas técnicas da escultura que ocorre no período helenístico; período de datação destas peças sículo-púnicas em especial.

Ao incluir em nossa análise as legendas que estes tetradracmas trazem, significando os locais de cunhagem ("campo/exército") e quem as emite ("as pessoas do acampamento militar/os eleitos de Melqart/os controladores financeiros”) (Mildenberg 1957), fica definido o caráter militar e o contexto específico de emissão destas peças. Ao aliarmos o contexto de emissão com a leitura dos textos mencionados acima e com a análise das próprias imagens do cavalo, a idéia de uma intenção, por parte de Cartago, de transmitir simbolicamente seu poder guerreiro, e portanto, sua alta capacidade de sair vitoriosa nos embates, dificilmente pode ser negada. Em algumas destas representações, os reversos trazem como tipo secundário pequenas Nikés que coroam os cavalos.
Ao lado da palmeira, o cavalo sempre foi considerado como o tipo monetário representativo de Cartago, nas moedas da capital africana, em contraponto à figura da deusa feminina (Core-Tanit), desenhada com os mesmos traços das moedas gregas de Siracusa. No entanto, baseados apenas nos dados acima, será possível ir além e considerar o cavalo como verdadeiro símbolo de Cartago, de maneira análoga à coruja de Atenas, por exemplo?

De maneira geral, esse ponto é assumido pela maioria dos numismatas que tratam do assunto. $\mathrm{O}$ interessante da posição de Bayet é a argumentação que ele apresenta: o cavalo foi escolhido como símbolo de Cartago, para passar a imagem de cidade guerreira e vitoriosa nos seus contatos com os gregos, e foi uma escolha tão bem sucedida, como pode ser visto pelas imagens da iconografia monetária, que a lenda em torno da fundação de Cartago surgiu tomando-se por base essas imagens, e não o contrário, como normalmente se assume.

Assim, Timeu, que morre em Siracusa em c. 260 a.C., e é a fonte de Justino, teria utilizado o relato local para escrever sua obra. Retomando, a história bélica da cidade africana, o imaginário dos cavalos furiosos nos reversos (tanto apenas a cabeça como também por inteiro), teria levado o mundo grecoromano à concepção greco-latina do cavalo como símbolo de fundação de Cartago, presságio do caráter conquistador da colônia fenícia.

Entendendo-se, pois, o cavalo como tipo escolhido para passar uma mensagem específica, de força e beligerância da cidade, algumas hipóteses para as origens do tipo foram levantadas por Bayet (1941: 178).

Mantendo-se na análise do Oriente, Bayet apresenta a possibilidade de o cavalo ter sido adotado com base no conceito de força, ferocidade e rapidez que este animal possui entre os povos orientais (semitas, assírios e filisteus). Através da análise do texto bíblico é possível recuperar a importância do cavalo para as populações semíticas. Eles teriam um caráter de força, rapidez e ardor nos combates (Cheyne \& Sutherland, apud Bayet 1941: 183). 
Assim, temos o cavalo de guerra dos assírios e dos filisteus (Livro de Jó, XXXIX, 18, 26 = com os dentes arreganhados e as narinas abertas).

A teoria que liga o cavalo à imagem de força guerreira, em nossa opinião, é a que mais se adequa às questões que foram aqui apresentadas. Este animal, que não aparece comumente na iconografia geral púnica, deve ser visto como uma imagem simbólica da força de Cartago, e até podemos aventar a hipótese de ele ter sido escolhido para representar a cidade africana perante aos outros povos com os quais manteve contato, na maioria das vezes, belicosos. Assim, podemos aventar a hipótese de ter ocorrido uma revitalização de um aspecto cultural específico oriental que, em termos evolutivos, alcançou a posição de símbolo de um estado perante aos povos greco-romanos.

Desta maneira, devemos analisar o tipo do cavalo dentro do contexto do período clássico, quando a iconografia monetária foi usada na afirmação política da autonomia da cidadeestado. No período helenístico, época das emissões reais berberes, haverá uma transformação na escolha dos tipos monetários que irão passar, gradativamente, não mais a representar as póleis e sim os indivíduos governantes dos grandes estados que serão formados. Contudo, a força dessa transformação já se faz sentir anteriormente em Cartago, quando estes reproduzem o tipo monetário com a figura de Héracles que aparece pela primeira vez na cunhagem de Alexandre, o Grande, ou ao imprimir as imagens do prótomo de cavalo em 3/4. Ou seja, a sagacidade cartaginesa e o seu pleno entendimento das possibilidades de uso propagandístico da cunhagem não podem ser negados. Eles vão cunhar utilizando imagens gregas (Core e Héracles) aliadas a outras, orientais e africanas: o próprio cavalo como símbolo cartaginês máximo, mas também a palmeira e os pequenos símbolos religiosos, entre outros. Além disso, temos aliadas a essas imagens legendas em púnico que, mesmo não inteligíveis para a população grega da Sicília, representam uma marca cultural muito forte.

Como interpretar as imagens do cavalo livre, galopando, dando passo e ou com arreios das cunhagens númidas de Massinissa e de seus sucessores (tipos 9, 12, 13, 14, 15)? Tendo em mente o que discutimos com relação à figura do cavaleiro númida, cujo imaginário aparece tão fortemente construído na estela de Chemtou e nas placas de terracota italianas, acreditamos que um contexto alimentou o outro. Isto é, Cartago foi um poder militar que fez valer essa reputação em sua propaganda política, essencialmente porque sabemos que a capital africana passa a produzir um numerário próprio muito tarde em sua História, pressionada pela necessidade de inserção econômica e política na Sicília.

Este contexto semítico-cartaginês, por seu lado, alimentou e foi alimentado pela própria força guerreira que está implícita nas chefias berberes (Kormikiari 2000: 117-188). Cartago dependia dos chefes berberes menores e mesmo dos grandes agellids (reis) centralizados para a manutenção de seus contigentes e, principalmente, para formar a temida cavalaria númida. Assim, acreditamos ser exeqüível supor que este imaginário, que como bem fundamentou J. Bayet, foi perpetuado histórica e culturalmente em ambiente grego através do relato mítico da fundação de Cartago, esteve igualmente presente no ambiente norte africano berbere. Desse modo, ganha sentido a reprodução, na cunhagem númida, do cavalo cartaginês. O cavalo dando passo (tipo 9) pode ser considerado quase como uma cópia direta do tipo de reverso dos últimos bronzes púnicos. A metrologia e a tipologia demonstrariam, a não ser pela figura de anverso e pela legenda do reverso, uma preocupação em tornar assimilável a cunhagem.

Massinissa possui ainda em sua cunhagem própria (emissão cabeça laureada) um tipo iconográfico novo entre os númidas: o elefante caminhando (tipo 8). Este tipo aparece na cunhagem cartaginesa, justamente nas emissões dos Barca, com as imagens masculinas laureadas, coroadas e imberbes. Os tipos cartagineses de anverso: cabeça masculina barbada, maça e coroa de louros; e cabeça masculina imberbe têm como reverso um elefante africano caminhando, com seu cornaca. Este é, sem dúvida alguma, o celebrado elefante de guerra 
de Aníbal, animal que junto ao leão, representa o próprio Norte da África. No entanto, o tipo do elefante aparece apenas na emissão laureada (tipo 7), atribuída a Massinissa. Esta é considerada mais antiga, do final da II ${ }^{a}$ Guerra Púnica. Isto é, o contexto político da época, a posição política contrária a Cartago que Massinissa adota, seu auxílio em Zama, a derrota de Aníbal, podem servir como pano de fundo para a escolha do elefante na primeira cunhagem de Massinissa. ${ }^{17}$

Com relação à circulação desse primeiro numerário númida, a partir de achados monetários, notadamente da área de Cirta e do vale do Medjerda (IGCH 2304 e 2305 achado de 1000 peças de bronze, cartaginesas e númidas, das quais apenas uma é de chumbo, nas proximidades de Teboursouk, Berberia Oriental) percebemos a grande quantidade de moedas númidas com o cavalo galopando que foram emitidas. Ainda no Vale do Medjerda, G. Camps assinala peças encontradas fortuitamente e em escavações na Tunísia (Gabès, Bulla Regia, Ain el-Hout), no resto da Argélia (Tipasa, Cherchel, Siga), e até no Marrocos (Banasa, Tamuda). Mas nesse último caso são, mais constantemente, exemplares isolados ou em pequenos grupos. Já ao redor de Constantina e para o norte da cidade, até Philippeville, essas peças abundam: e seu estado deteriorado demonstra que estiveram durante um longo tempo em circulação (Camps 1960: 207). O Cel. Baradez encontrou peças de chumbo em contexto arqueológico do século I d.C., nas tumbas de Tipasa, cidade entre Iol e Icosium, na costa mediterrânica da Berberia Central (Baradez 1957: 226, apud Camps 1960: 206).

Após uma série de trabalhos arqueológicos realizados no sítio da Cartago romana em 1896, A.-L. Delattre encontrou c. 300 moedas, $2 / 3$ destas eram ou púnicas ou

(17) Na opinião dos pesquisadores do santuário de ElHofra, em Cirta (Constantina), que analisaram a iconografia das estelas púnicas deste, o elefante de Massinissa estaria ligado aos ritos do símbolo solar, ao mesmo tempo em que estaria consagrado à Eternidade (Berthier \& Charlier 1952: 198, apud Voisin 1983: 32). númidas, estas últimas, menos numerosas (Fischer 1978: 38). Todas possuíam módulos grandes (c. $27 \mathrm{~mm})$. Trata-se dos grandes bronzes púnicos e de Massinissa. O arqueólogo acreditava que estas moedas se encontravam em contexto funerário por terem ganho significado religioso após terem saído de circulação. Um outro pesquisador propôs o contrário. As moedas anteriores ao Império haviam permanecido em circulação, para transações diárias de pequeno porte, em razão de terem mantido um valor fiduciário (Cagnat 1909: 202, apud idem). Por fim, em Lambèse, campo militar edificado durante o principado de Adriano, no século II d.C., para abrigar a III ${ }^{a}$ Legião Augusta, ao lado de diversas moedas imperiais romanas foram encontradas, em escavações arqueológicas, 11 peças cartaginesas e 24 númidas (Fischer 1978: 39). O arqueólogo considera que todas as moedas pertenciam aos legionários ou a pessoas ligadas à Legião, e reafirma sua opinião anterior, que estas moedas cartaginesas e númidas eram utilizadas ainda nos séculos II e III d.C. para pequenas transações comerciais.

Por outro lado, em Cirta peças estrangeiras também circulavam a partir do reino de Micipsa, isto é, 148 a.C.. Micipsa foi o primeiro sucessor de Massinissa. Ali foram encontradas, em grande quantidade, peças de Rodes, Cartago, Cirene, Massalia e Roma: segundo Estrabão - XVII, 3, 13 - Micipsa incentivou o assentamento de estrangeiros em Cirta (apud Burnett 1987: 177). O tesouro de Constantina, que contém 237 peças de prata enterradas por volta de 79 a.C., só possuía moedas estrangeiras: Atenas, Cartago, Massalia, Iberia e sobretudo Roma (Camps 1960: 207) mas, em razão de sua datação, reflete a continuidade da presença estrangeira no interior da Numídia

G. Camps já havia assinalado a descoberta de dois achados monetários encontrados nos Balcãs, um em Kula (Bulgária) e o outro em Mazin (Croácia) (Camps 1960: 208-209). Este último não continha menos de 328 moedas númidas. É nesta região da Ilíria que foi encontrado o conjunto mais importante de peças númidas. As moedas de Ptolomeu X Soter, associadas às númidas no achado, 
permitem que o depósito seja datado do ano 80 a.C.. Uma outra moeda númida foi descoberta na Armórica, perto do estuário de Léguer.

É justamente da França que vem o maior número de achados monetários númidas. Foram elencados onze achados monetários númidas de Massinissa e seus sucessores (Fischer 1978: 108-129). A autora acredita que estas moedas estejam relacionadas à penúria monetária da Gália neste período, que dura das guerras gálicas até o reino de Augusto. Então, as tropas de mercenários de Massinissa e dos reis berberes teriam movimentado a economia com seus soldos, e insuflado as populações locais a utilizarem este numerário estrangeiro (idem: 142-149).

Desse modo, a nosso ver, o quadro que surge é um bastante concreto. Massinissa suplanta Sífax e colabora para sua expulsão de Cirta. O reino massilo surge tendo como centro justamente esta região. Trata-se de uma área berbere tradicional, no interior da atual Argélia, mas que recebeu, desde a época cartaginesa, um grande influxo de estrangeiros que ali vinham habitar. As aldeias indígenas, nos sopés das montanhas, entre estas dos Aurès, os vales dos rios locais, a própria bacia do Hodna e de Constantina foram densamente habitados para os padrões da Antiguidade. Massinissa e seus sucessores tiveram que sustentar seu poder tanto entre os berberes, e neste sentido os chefes menores eram os grandes mediadores das relações, mas também entre os estrangeiros que já começavam a chegar. Igualmente não podemos esquecer os próprios cartagineses, isto é, os libifenícios. Neste contexto, tanto a iconografia quanto o esforço de produção monetária dos primeiros reis númidas ganham coerência. Inicialmente as moedas de Massinissa são devedoras do sistema ponderal cartaginês e igualmente de sua iconografia. Nesta iconografia foram introduzidas inovações, adequações necessárias em razão da estrutura social da qual este numerário era produto e na qual ele devia atuar. Estamos falando particularmente dos retratos e das variações nas feições, em nosso entender uma busca da autenticidade.

Sífax inicia o processo. Mais significativamente, ainda que sua cunhagem tenha sido incipiente, e tendo ou não se associado a seu filho, Vermina, Sífax é o único soberano berbere que foi capaz de emitir numerário próprio enquanto Cartago ainda era uma força atuante. Os pormenores deste contexto nos escapam, mas acreditamos que a representação do cavaleiro númida, senão do próprio chefe dos cavaleiros númidas, no caso o próprio Sífax, demonstra sobre quais bases esteve assentado esse poder. A iconografia de Vermina é voltada para o imaginário propriamente cartaginês, apesar de não podermos negar que o cavalo, enquanto símbolo de rapidez e força, adequava-se perfeitamente ao ideário das chefias berberes. É justamente este imaginário que é adotado por Massinissa e seus sucessores, o cavalo galopando, parado, dando passo. A escolha dessa iconografia buscava, naturalmente, uma aceitação. A escolha de tipos familiares, então, era necessária. $O$ vasto raio de penetração da cunhagem de Massinissa, nesse sentido, como vimos pelas notícias da circulação monetária, demonstra que estas peças, junto com as cartaginesas, que ademais traziam os mesmos tipos de reverso (cavalo galopando, cavalo dando passo), foram aceitas pelas comunidades as mais diferentes (os achados vêm de sítios berberes como Tiddis e romanos como Lambèse, e fenício-cartagineses como Gightis). Seu caráter cotidiano e localizado também aparece nos metais empregados, bronze e chumbo. Seria este um sinal da pobreza dos reinos berberes ou o metal mais precioso saiu de circulação para ser entesourado como propõe G. Camps (1960: 210)?

As imagens mais fortes desse imaginário de poder militar (o cavalo virando para atacar) não aparecem nas moedas númidas. No entanto, entendemos que este é um aspecto natural do processo, uma vez que as peças mencionadas (os mais belos exemplares aparecem nos tetradracmas cartagineses cunhados na Sicília no século IV a.C.) fazem parte do momento inicial de transformação da imagem em mensagem. Uma vez 
conseguida a associação, o cavalo por si só já comportava o significado completo.

\section{Jugurta (?)/Hiêmpsal II (?)/Hiarbas (?)}

A atribuição de um numerário a Jugurta e Hiêmpsal II, entre os númidas, e Hiarbas, o suposto usurpador getulo, é hipotética.

No caso de Jugurta, segundo J. Mazard, baseia-se na tradição. $O$ próprio autor duvidava dessa atribuição. Assim, L. Müller acreditava que o único tipo conhecido e atribuído por ele a Jugurta (tipos 16 e 17) possuía uma iconografia e um estilo (na textura da fabricação) tipicamente africanos (1861: 34). Na verdade, Müller estava apenas seguindo um numismata anterior, Duchalais, o qual pretendia ligar esta série de prata a um denário cunhado em honra a Sila (Mazard 1955: 44). Mais recentemente, A. Burnett invalidou categoricamente a atribuição de uma cunhagem em prata a Jugurta, que era a única que conhecíamos (Burnett 1987: 176). Este numismata argumenta que arqueologicamente não foram recuperados traços numismáticos da Guerra de Jugurta. Além disso, de acordo com Salústio (Jugurthinum, XXIX, 6: LXII, 5), Jugurta efetuou pagamentos em barras de prata. Como já

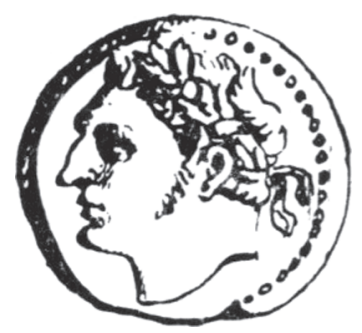

Tipo 16. Mazard (1955: 45 - tipo 73). (x 1,5)

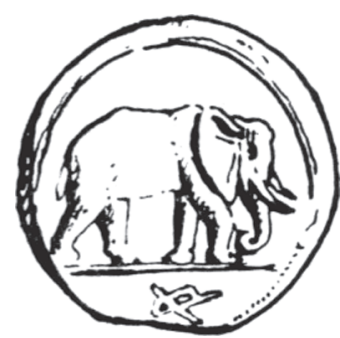

Tipo 17. Mazard (1955: 45 - tipo 73). (x 1,5) mencionamos, Salústio relata também (Jugurthinum XXVII, 5; XXXVI, 1) que, em 111 e 110 a.C., os romanos mandaram dinheiro, stipendium, com seus exércitos para a África.

Assim, a informação negativa (falta de achados arqueológicos) impede que possamos atribuir efetivamente uma cunhagem a Jugurta. As séries que Mazard elenca trazem uma letra púnica (A) e o elefante caminhando, sem cornaca, no reverso (tipo 17). Estes seriam os únicos elementos "africanos" desta peça. A cabeça masculina do anverso (tipo 16) difere totalmente dos retratos númidas que acabamos de analisar. Os númidas são descritos pelas fontes com cabelos ondulados, e, aparentemente, a barba pontuda tornou-se uma marca dos primeiros reis númidas. A iconografia não parece, portanto, incentivar uma atribuição a Jugurta. A não ser pelo único elemento que poderia ser ligado à propaganda africana, o elefante, o qual poderia significar uma tentativa, por parte de Jugurta, de associar-se à imagem de Massinissa, mais precisamente, ao culto real. Por outro lado, a opção em não utilizar o tradicional tipo do cavalo seria facilmente compreensível, uma vez que Jugurta guerreou, igualmente, contra seus primos.

A atribuição da cunhagem a Hiêmpsal II baseia-se na legenda H HT de reverso (Mazard 1957: 155). Partimos do pressuposto de estarmos, de fato, diante da cunhagem de Hiêmpsal II, númida que ascende ao poder enquanto sucessor de seu pai, Gauda (Hiêmpsal é tido como "rei aliado e amigo" do povo romano - Mazard 1955: 45), após 105 a.C.. Gauda, por sua vez, havia sido colocado no posto pelos romanos, por obra de Mário, a nos fiarmos nas fontes, após a Guerra de Jugurta. Desconhecemos uma cunhagem de Gauda, de maneira análoga a outros reis númidas.

No entanto, seguindo o método de divisão do poder entre vários irmãos herdeiros, o que parece ter acontecido em certos momentos mesmo sendo uma deturpação da sucessão agnatícia berbere, na qual o membro mais velho da família ascendia ao poder, Gauda divide o reino da Numídia (já territorialmente diminuído em razão da anexação do rei mouro Boco I), supostamente entre seus dois filhos, 
Hiêmpsal II e Masteabar. Este último reinou na parte ocidental dessa nova Numídia.

Desconhecemos séries monetárias que possam ser atribuídas a Masteabar. Por outro lado, Hiêmpsal II supostamente cunhou em prata, ouro e bronze, ou seja, no conjunto completo de denominações. No entanto, o mesmo argumento utilizado por Burnett para negar uma cunhagem em prata a Jugurta se aplica igualmente para Hiêmpsal. Entretanto, a legenda das peças de prata e bronze, H HT, pode ser traduzida como "Pessoa real de Hiêmpsal". As duas séries em ouro foram classificadas por J. Mazard para Hiêmpsal a partir de ligações tipológicas e de estilo subjetivas.

Acreditamos, não obstante, poder interpretar as moedas de Hiêmpsal II à luz da contextualização já realizada acerca da História da sucessão númida e dos dados que uma estela dedicada a Hiêmpsal, descoberta em Rodes, oferece. Hiêmpsal fica com a parte mais rica do reino, a parte oriental. $\mathrm{O}$ vale do Medjerda e a região de Cirta. Esta área era excelente produtora de grãos. Por outro lado, uma dedicatória a Hiêmpsal II, encontrada em Rodes, é um documento único que atesta pela primeira vez a presença, mesmo que apenas comercial, desse rei númida em terras gregas (Kontorini 1975: 96-97). Isto posto, acreditamos que os tipos 18 e 19, constituídos por divindades no anverso (Ceres? Triptolemos? Ou seus correspondentes númidas?), ornadas com coroas de grãos, e o cavalo com coroa de louros no reverso, façam referência explícita à riqueza das terras sob controle de Hiêmpsal. ${ }^{18}$ Não obstante, a falta de uma datação mais precisa para as séries torna nossa segunda proposta conjectural. Sabemos que Hiêmpsal II foi deposto pelo getulo Hiarbas (c. 108 a.C.) e depois retornou ao poder com a ajuda dos romanos e do rei mouro Boco I. Assim, os tipos 20 e 21, com a efígie da Vitória no anverso e o cavalo livre no reverso, pode ter

(18) César vai bater denários na África, em 46 a.C., nos quais ele manda colocar no anverso a figura de Ceres, simbolizando a carga anual de trigo que ele havia conseguido garantir para Roma (Perez 1989: 96).

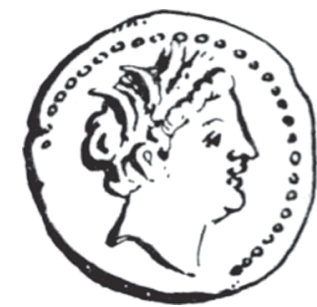

Tipo 18. Mazard (1955: 47 - tipo 78). (x 1,5)

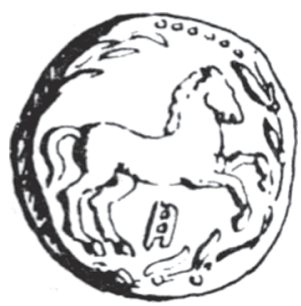

Tipo 19. Mazard (1955: 47 - tipo 78). (x 1,5)

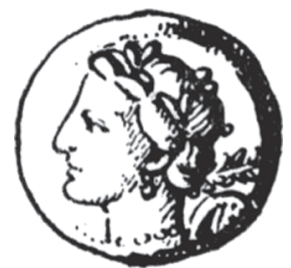

Tipo 20. Mazard (1955: 46 - tipo 77). (x 1,5)

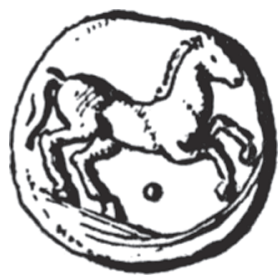

Tipo 21. Mazard (1955: 46 - tipo 77). (x 1,5)

um caráter comemorativo, de retorno ao reino e deposição do usurpador. De maneira análoga, a coroa de louros comemoraria esta mesma vitória. Temos, então, a inclusão de tipos iconográficos claramente estrangeiros. Partindo para uma explicação inerente à sociedade berbere, a vitória sobre Hiarbas deve ter movimentado clãs e famílias, e essa vitória seria, então, não um símbolo do poder individual do rei, mas do grupo como um todo.

Os reversos de todas essas séries é o tradicional cavalo púnico e, desde Massinissa, 
númida. Ao invés de estar pregando seu caráter guerreiro, o cavalo é um retorno imagético à concepção da família massila. As moedas com o cavalo galopando são as mais difundidas em termos de circulação monetária. Assim, enquanto Jugurta pode ter querido se ligar ao poder real através somente de Massinissa, Hiêmpsal teria querido se associar à família agnatícia como um todo.

Hiarbas, esse usurpador desconhecido (getulo? chefe menor de alguma facção númida, mesmo massila?) possui duas emissões que lhe foram atribuídas por Mazard (tipos 22 e 23). J. Mazard considerava Hiarbas o primeiro rei dos massilos do ocidente (Mazard 1955: 53). As legendas IL e TWS, TVZ ou TWN, e TN foram lidas como nomes de cidades da Berberia central (Iol e Tuniza). A leitura de Iol (IL) é hipotética e efetivamente não faria sentido sendo Hiarbas um getulo vindo da região meridional dos Aurés, isto é, da Berberia Oriental, e estando Iol localizada na costa central argelina. A área de Iol, neste momento, estava sob o poder do rei mouro Boco I, o qual havia recebido as terras númidas até o rio Ampsaga, localizado a leste de Iol. Já a outra legenda, com mais variações e portanto mais freqüente, não apresentaria este tipo de problema porque a área de Tuniza (atual La Calle) está na fronteira entre a Africa vetus, antiga região

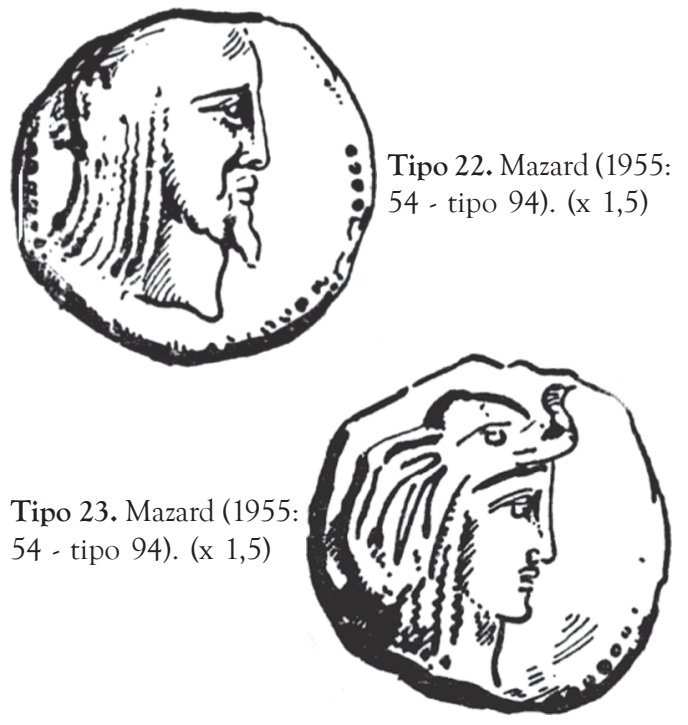

cartaginesa, e o reino da Numídia Oriental tomado por Hiarbas de Hiêmpsal II, por alguns anos.

J. Mazard, seguindo L. Müller, acredita que a imagem masculina, com longos cabelos em cachos regulares seja o retrato de Hiarbas (tipo 22). No reverso, por vezes, temos novamente o cavalo dando passo, mas um tipo novo na iconografia monetária real berbere aparece: a personificação da África através da imagem de uma cabeça feminina vestida com a pele de elefante (tipo 23). ${ }^{19} \mathrm{Em}$ 71 a.C., Pompeu manda bater, na oficina de Roma, áureos com a personificação da África no anverso (RRC 402). Estas séries foram batidas para comemorar seu triunfo. A escolha de um tipo "pompeiano", na verdade, de um símbolo do território conquistado pelos romanos, pode ser interpretada enquanto afirmação política ou, justamente o contrário, enquanto concessão ao poder maior romano?

O contexto de emissão dos supostos numerários de Jugurta, Hiêmpsal II e Hiarbas é o de embates com o poder romano (Guerra de Jugurta) e o da transferência das lutas internas romanas para solo estrangeiro, africano. A sociedade norte-africana, como um todo, as populações das cidades, das aldeias, os grupos indígenas, seus chefes menores e os reis berberes foram todos obrigados a se posicionarem diante dos acontecimentos. As cunhagens destes reis berberes, aparentemente, não deixaram rastro no registro arqueológico. Duzentos anos mais tarde é possível encontrar ainda moedas cartaginesas e dos primeiros númidas em localidades as mais variadas. No entanto, a rica cunhagem de Hiêmpsal, por exemplo, parece ter ficado presa a seu período específico.

Este momento também é marcado pelo aumento das emissões citadinas locais. $\mathrm{O}$ uso da moeda no Norte da África torna-se

(19) A pele de elefante (exuviae elephantis) e o leão são considerados atributos da dea Africa sob o Império por M. Le Glay (1964, apud Voisin 1983: 34). 
restrito em certas áreas. Os romanos ainda não estão batendo moedas em solo africano e continuavam despachando dinheiro direto de Roma para sustentar os diferentes partidos em guerra (Plutarco, Pompeu, II, apud Burnett 1987: 176).

Surpreende-nos apenas a falta de vestígios, no Norte da África, da Guerra de Jugurta. ${ }^{20}$ Se este efetivamente possuía em seu exército mercenários, ou como acreditamos, paralelamente ao menos, dependia da coesão dos chefes menores e de sua adesão tanto ao rei quanto à causa, a necessidade de pagar os mercenários e de prestigiar os chefes indígenas teria sido feita apenas com metal em barras como conta Salústio? Nos parece incoerente a opção pelo não uso do metal cunhado enquanto meio propagandístico. No entanto, a falta de dados é muito grande e a conjectura apenas não nos esclarece acerca das reais causas dos acontecimentos.

\section{Dinastia massila ocidental: Capussa, Mastenissa e Arabion}

J. Mazard não atribui cunhagem a Capussa. No entanto, em 1978, um achado monetário em péssimo estado de conservação foi resgatado, a partir de escavações arqueológicas subaquáticas na Baía de Cavalaire, em Lavandou (Var). Das onze peças encontradas, cinco são moedas de Massalia, uma de Corteia (Bética) e cinco do reino númida. O tipo monetário destas últimas é o tradicional cabeça masculina laureada com barba, no anverso (tipo 7), e cavalo livre galopando, no reverso (tipo 12). A

(20) Denários batidos em Roma, em c. 56 a.C., recuperam a memória dessa guerra. $\mathrm{O}$ anverso traz a imagem de Diana e o lituus, o bastão dos que praticavam os augúrios (relambrando, aqui, o sacerdócio exercido por Sila). No reverso, Sila aparece sentado em posição de magistrado romano (em uma cadeira curul e com sua toga), de cada lado há um personagem: à esquerda, Boco I, rei da Mauritânia, decretado amicus populi Romani, estende ao ditador um ramo de oliveira; à direita, Jugurta, rei do númidas, cabeça abaixada e mãos presas às costas, demonstra pela sua atitude, sua aflição e sua derrota. $\mathrm{O}$ ramo de oliveira, o qual Boco estende a Sila, evoca a oferenda do ramo simbólico em ouro, consagrado por este rei ao Capitólio (Perez 1989: 76). diferença destas peças é a nova legenda que foi, então, descoberta. No reverso, em púnico, aparecem duas letras KN. Seguindo a tradicional leitura do nome abreviado berbere, G. Camps leu Capussan (Camps 1984: 29-30). O módulo da peça, $27 \mathrm{~mm}$, os tipos iconográficos e o metal no qual foram cunhadas, chumbo, parecem confirmar que pertençam a um membro da família de Massinissa, Capussa, o qual ensaiou ascender ao poder um pouco antes de Massinissa, mas que aparentemente morreu logo após o início de seu reinado em 207 a.C., sem que saibamos exatamente como.

As peças em questão, no entanto, parecem apontar uma nova hipótese de trabalho. Sabemos que os sucessores imediatos de Massinissa (Micipsa, Gulussa, Aderbal, e outros) emitiram numerário seguindo a tipologia iconográfica de Massinissa, apenas com variações nas denominações. As moedas do módulo das encontradas com legenda KN costumam ser atribuídas a Massinissa e são datadas do início de seu reino (c. 207 a.C.), pois seguem o padrão monetário das últimas emissões cartaginesas de bronze. Nos perguntamos quanto à possibilidade de Capussa ter reinado junto com Massinissa, ou então, de Massinissa ter se apossado da iconografia monetária do herdeiro autêntico da família massila (Capussa era, provavelmente, o filho mais velho de Oezálces, por sua vez, o parente mais velho por ocasião da morte de Gaïa, o líder massilo então). Quando Capussa morre, somos informados pelas fontes textuais que a ordem das coisas é momentaneamente subvertida, pois quem ascende é um irmão de Capussa, Lacumazes, ainda uma criança. Massinissa tem que guerrear para obter o lugar que seria seu por direito, visto que, então, ele passa a ser o familiar mais velho. Lacumazes igualmente morre e, assim, nos perguntamos se a escolha iconográfica da cunhagem de Massinissa não teria a intenção de reafirmar a sua legitimidade enquanto herdeiro. Assim sendo, o segundo tipo de reverso das moedas de Massinissa, o elefante (tipo 8) ganha novas conotações. Este seria, definitivamente, um símbolo da vitória de Massinissa em Zama.

Capussa foi identificado como um dinasta 
dos massilos ocidentais porque, em 207 a.C., Sífax estava ativo e possuía Cirta, na região oriental, dentro de seus territórios. Somente com as conquistas territoriais de Massinissa é que veremos o reino dos massilos se estender para o oriente da Berberia Central.

Mastenissa e Arabion reinaram na Numídia Ocidental enquanto Hiêmpsal II e Juba I estavam no poder na Numídia Oriental. A iconografia destes dois reis da Numídia Ocidental liga-se tanto a estas localidades quanto à suposta cunhagem de Hiarbas, o usurpador. Os tipos de anverso masculinos seriam os retratos dos reis (tipos 24 e 25, Arabion e tipo 26, Mastenissa). Estilisticamente seguem o retrato das moedas de Hiarbas. Se Hiarbas cunhou suas peças em Tuniza, na costa oriental da Berberia, é possível tentarmos estabelecer algum tipo de contato entre as suas cunhagens. No entanto, igualmente para esses reis não possuímos achados monetários que possam nos auxiliar a elaborar hipóteses de trabalho. As fontes textuais latinas e gregas também não nos auxiliam, pois de acordo com os relatos, Mastenissa e Arabion apoiaram a causa de Pompeu, e Hiarbas a de Mário. Por que os massilos ocidentais teriam querido se apoderar da construção imagética do rosto do soberano getulo? Uma boa saída seria retirarmos a atribuição a Hiarbas das peças de cabeça masculina com cabelos longos e personificação da África, e transferi-las para Mastenissa. Desse modo, Hiarbas ficaria sem cunhagem, mas não seria o primeiro rei berbere a ficar, assim, despossuído.

No que concerne aos reversos destas moedas de Mastenissa (tipo 27) e Arabion (tipo 28) acreditamos estar diante de duas iconografias locais. Os cachos de uva e os grãos são encontrados nas cunhagens contemporâneas de cidades como Gunugu, Timici, Camarata, Tamuda, Sala, Rusadir. Isto é, ao longo de toda a costa berbere (o sítio de Gunugu foi localizado na Berberia Central, próximo a Iol, e o de Sala, por exemplo, está na costa atlântica, extremo oeste da Berberia Ocidental). A interpretação imediata destas imagens diz respeito às condições básicas da vida social: agricultura, plantio, riqueza da terra. A imagem da divindade feminina velada que aparece nas moedas de Arabion, por outro lado, liga-se, em

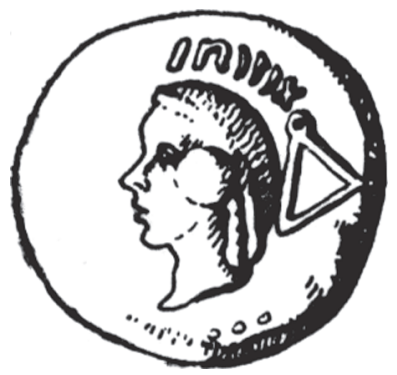

Tipo 24. Mazard (1955: 56 - tipo 102). (x 1,5)

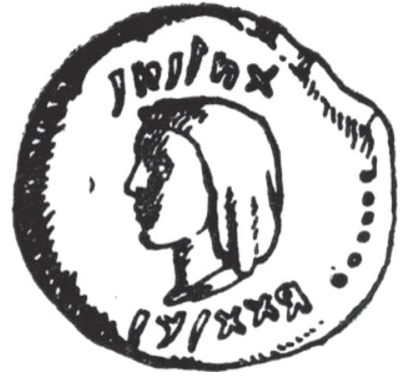

Tipo 25. Mazard (1955: 56 - tipo 101). (x 1,5)

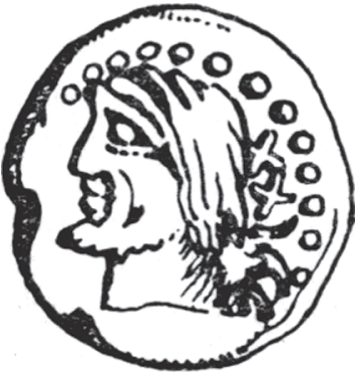

Tipo 26. Mazard (1955: 55 - tipo 99). (x 1,5)

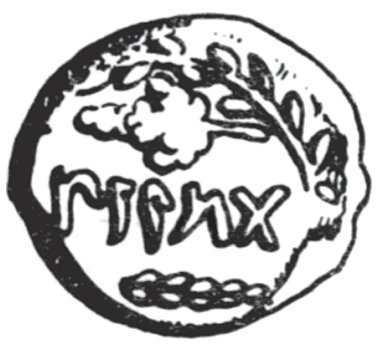

Tipo 27. Mazard (1955: 55 tipo 100). (x 1,5)

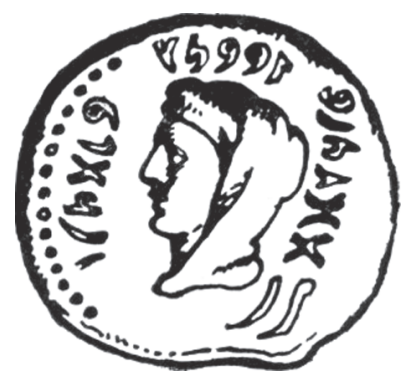

Tipo 28. Mazard (1955: 56 . tipo 101). (x 1,5) 
nosso entender, ao panteão local. Mais especificamente de Thabraca, pois uma legenda de reverso, em neo-púnico, traz provavelmente o nome da cidade (TBRS). O símbolo de Tanit que aparece em algumas peças de Arabion, no anverso, é, em nossa opinião, uma contramarca e não deve ser lido a partir de uma possível conexão com a divindade do reverso. Praticamente desconhecemos a construção imagética da própria figura de Tanit entre os púnicos (afora os atributos crescente, símbolo de Tanit - com ressalvas -, e caduceu, os quais aparecem profusamente nas moedas cartaginesas, púnicas e neo-púnicas não possuímos qualquer imagem física da divindade, de modo que não podemos associá-la à figura velada do reverso de Arabion).

A cunhagem de Arabion comporta ainda uma legenda de difícil leitura, em neo-púnico, colocada ao redor do campo monetário: Balmuzelan, filho de Cabirzo, filho de Muzelan (?). Acreditamos estar diante, talvez, de uma referência ao moedeiro responsável pela cunhagem. De maneira análoga às longas inscrições da República Romana, as quais muitas vezes tomam boa parte da face monetária, teríamos aqui um raríssimo exemplo de uso tão extenso da língua púnica em uma moeda.

A partir dos dados que apresentamos acima, sobre as dinastias númidas de Jugurta a Arabion, cremos ser possivel estabelecer alguns fatos importantes para o entendimento das transformações na cunhagem real entre os berberes. Mesmo tendo cunhado em ouro e prata (confirmando-se a atribuição das moedas de Jugurta e Hiêmpsal II, o que parece não ser a tendência), os reis, através dos dados que a iconografia monetária nos fornecem, não mais nos parecem deter o mesmo poder guerreiro, do agellid. Jugurta moveu uma guerra local forte o suficiente para chamar a atenção de Roma e fazê-la mobilizar suas forças militares. Mas não encontramos nos vestígios numismáticos a mesma repercussão. A cunhagem parece ter sido usada enquanto meio de afirmação política muito claramente com Sífax e Massinissa, mas não tanto com Jugurta e Hiarbas. A cunhagem de Hiêmpsal II, ao contrário, se destaca, tanto iconograficamente quanto pela riqueza das denominações, mas com um outro caráter, o da riqueza da terra (divindades com com grãos) e não tanto da força guerreira (na verdade foram os romanos que subjugaram Hiarbas, o uso da Vitória, mesmo sendo de origem grega, e da coroa de louros parece-nos "inconscientemente" declarar o verdadeiro vencedor). Por outro lado, os reinos massilos do Ocidente demonstram uma total sujeição à sociedade urbana e à imagística regional. Fica claro nesses últimos que, apesar da manutenção da legenda especificamente designando-o como "pessoa real", o rei númida não possui o mesmo poder dos seus pares orientais. A questão não resolvida da posse da terra entre os berberes volta com força aqui. Hiêmpsal II, Mastenissa e Arabion, em última instância, são os únicos a apregoarem produtos agrícolas, não militares, em sua iconografia monetária. A sujeição à iconografia local, das cidades, insere tanto a apreensão da mensagem iconográfica quanto a circulação monetária dentro de limites físicos específicos. A não ser que venhamos a encontrar, em escavações arqueológicas e em notícias esporádicas, dados que nos permitam estabelecer uma vasta rede de trocas monetárias entre os reis (os territórios dos reinos mouros começavam no rio/oued Ampsaga, isto é, na fronteira com os massilos do Ocidente) e entre as cidades, em nosso entender, Mastenissa e Arabion foram mais provavelmente chefes menores do que reis berberes autênticos. Ainda que devamos sustentar a classificação de rei e a existência de uma divisão no reino númida a partir de Hiêmpsal II, em razão das legendas monetárias de Mastenissa e Arabion.

\section{Juba I}

Até o momento, isto é, meados do século I a.C., podemos afirmar que a cunhagem dos reis berberes está inserida, econômica e 
culturalmente, em ambiente púnico. As legendas são sempre em escrita púnica, bem como as contra-marcas, e os sistemas metrológicos igualmente são púnicos. A partir de Juba I, veremos uma mudança radical deste quadro. A Guerra Civil, entre César e Pompeu, tomou proporções grandes o suficiente no Norte da África, de sorte a levar à emissão de moedas na própria África, pelos dois lados. Uma quantidade razoável de denários (incluindo alguns quinários) foram batidos por Metelo Pio e Cato, em 47/6 a.C. (RRC 459-462), e também, provavelmente, pelos partidários de César (RRC 458).

Conforme mencionamos acima, os numismatas acreditam que somente neste momento foram cunhadas peças reais berberes em metal nobre (Burnett 1987: 176). Apesar de termos mantido, com ressalvas, as atribuições de moedas a Jugurta e Hiêmpsal II, concordamos que a cunhagem em prata de Juba I foi batida para ajudar a causa pompeiana. Possuímos inúmeras notícias de achados monetários com moedas de Juba I, encontrados no Mediterrâneo setentrional (da cunhagem de Juba I estavam representadas apenas seus denários). ${ }^{21}$ Estas notícias são datadas, em geral, de meados do século I a.C., de modo que a emissão do numerário de prata deste rei é igualmente datada do final de seu reino (Juba morre em 46 a.C.). Assim entre 47/46 a.C. Juba I empreende um grande esforço na produção de seu numerário de prata.

Estas emissões em prata demonstram, no que toca aos metais nobres, a adequação econômica africana ao sistema romano. Os denários de ambos, romanos e de Juba I, podiam ser utilizados em transações comuns, como o seu entesouramento conjunto em dezenas de exemplos assim o comprova. ${ }^{22}$ Iconograficamente as moedas de Juba I ligam- se também a Roma. Elencamos cinco tipos de anverso (29 a 33) e cinco de reverso (34 a 38). As legendas, em púnico e em latim, aparecem uma de cada lado. No anverso, REX IVBA ("Rei Juba") e, no reverso, SYWB'Y HMMLKT ("A pessoa real de Juba").

Os tipos iconográficos de Juba apesar de se aproximarem fortemente da imagética republicana romana (anverso: tipos 29 - cabeça de África; tipo 30 - templo octostilo; tipo 31 busto alado de Vitória; reverso: tipo 34 . palácio; tipo 35 - templo octostilo), mantêm ainda laços com a iconografia monetária real berbere até aqui descrita (anverso: tipo 32 . busto de Juba com os típicos cabelos encaracolados e barba pontuda númidas; reverso: tipo 36 - leão caminhando; tipo 37 - elefante caminhando; tipo 38 - cavalo livre galopando). Afora estes, temos pela primeira vez a cabeça de Amon (tipo 33) como tipo principal de anverso. Outro dado pertinente é o fato de as moedas de prata trazerem as legendas duplas e as de bronze não, apenas em púnico.

Com relação ao retrato, Juba I é um dos poucos soberanos númidas com os quais podemos fazer estudos comparativos a partir de diferentes suportes de figuração: moeda e escultura. Há, com efeito, uma cabeça em mármore, atualmente no Museu de Cherchel (Fig. 7), que representa o retrato deste rei. Nos dois documentos, escultura e denários batidos em Útica pouco antes do desembarque de César na África, vemos os mesmos cabelos encaracolados e a barba cheia, igualmente crespa. ${ }^{23}$ Encontramos nessa cunhagem "romana" do rei númida um primeiro símbolo africano, o penteado berbere, que conforme mencionamos ao falar do cavaleiro númida, é um traço étnico. No entanto, ao mesmo tempo em que se apresenta enquanto berbere, Juba manda gravar uma legenda em latim, no nominativo, que é tipicamente romano, e não no genitivo, que seria tipicamente grego

(23) Cícero teria ficado surpreendido com essa vasta cabeleira, tão diferente do modelo romano, ao encontrar Juba I em Roma (Cícero, De lege agraria, II, 22, 59, apud Mazard \& Le Glay 1958: 15). 


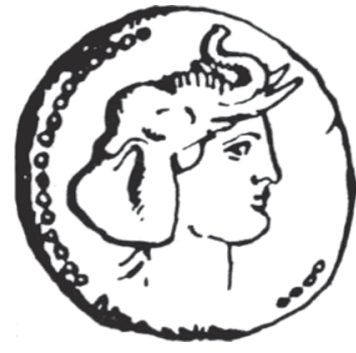

Tipo 29. Mazard

(1955: 52 - tipo 93). (x 1,5)

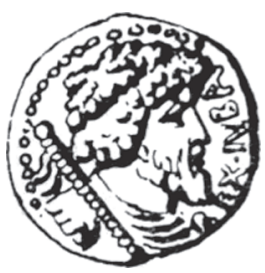

Tipo 32. Mazard (1955: 50 - tipo 84). (x 1,5)

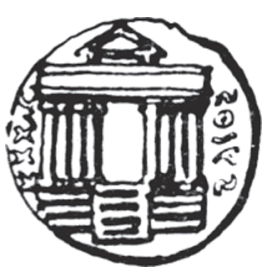

Tipo 35. Mazard (1955: 50 - tipo 85). (x 1,5)

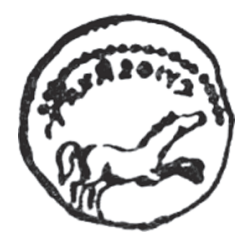

Tipo 38. Mazard (1955: 50 - tipo 87). (x 1,5)

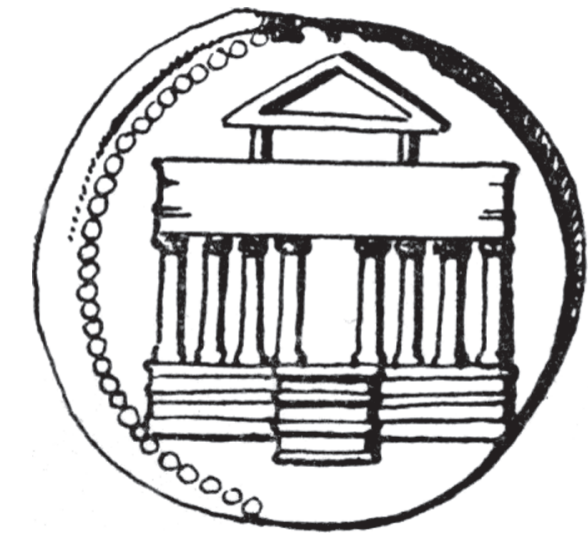

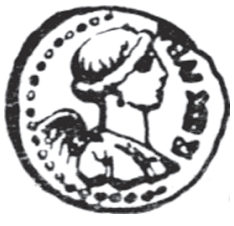

Tipo 31. Mazard (1955: 50 - tipo 87). (x 1,5)

Tipo 30. Mazard

(1955: 51 - tipo 91). (x 1, 5)

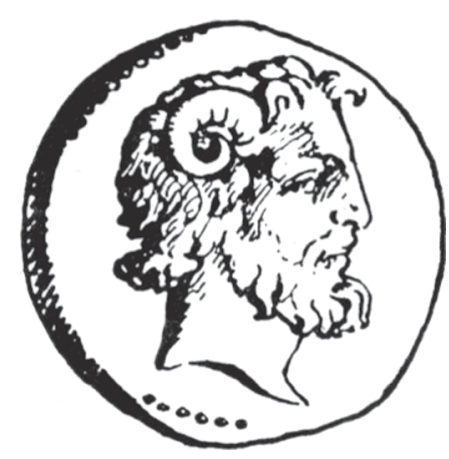

Tipo 33. Mazard (1955: 51 - tipo 90). (x 1,5)

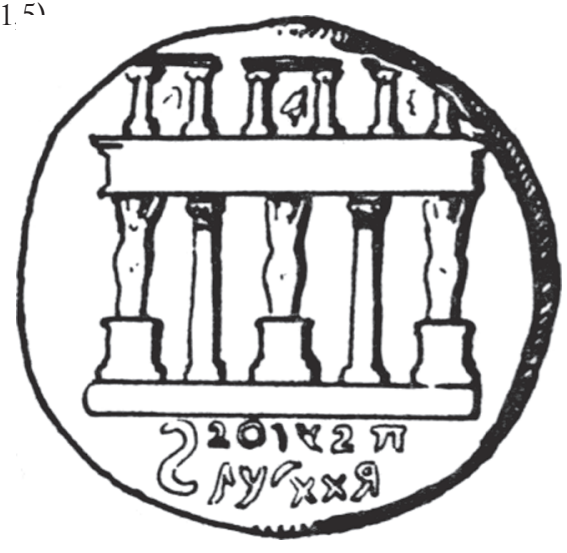

Tipo 34. Mazard (1955: 51 - tipo 91). (x 1,5)

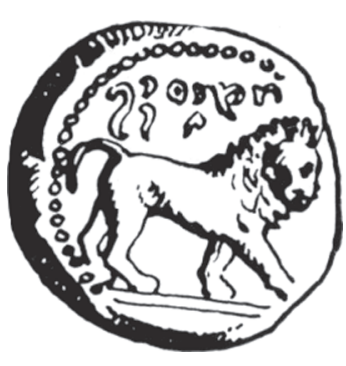

Tipo 36. Mazard (1955: 52 - tipo 93). (x 1,5)

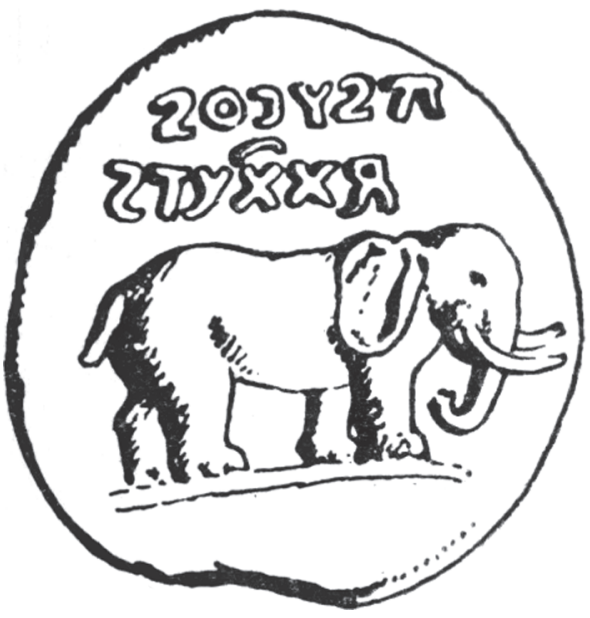

Tipo 37. Mazard (1955: 51 - tipo 90). (x 1,5) 
(Bertrandy 1980: 12). Além disso, todos os soberanos númidas tiveram suas legendas designativas gravadas no reverso (de fato, a versão em púnico do título real aparece nos reversos desse mesmo tipo monetário com o retrato). Estas peças apresentam uma grande novidade na numismática númida: construções. A primeira é um templo octostilo (tipos $30 \mathrm{e}$ 35). As colunas, agrupadas de quatro em quatro, estão sobre um pódio. No centro, uma entrada pode ser vista, inclusive o acesso, o qual é feito por quatro degraus (neste espaço foram colocadas contra-marcas diferentes para cada série, um, dois ou três glóbulos). O entablamento horizontal sustenta uma edícula de dimensões reduzidas. Esta é coberta por um telhado de duas águas, e em frente deste, um frontão. Bertrandy chama a atenção para o fato de que este frontão não é tipicamente greco-romano, pois ele não cobre todo o entablamento.

A segunda é um palácio (tipo 34), edifício cujo centro é composto por uma fachada pentastila. Três atlantes, separados uns dos outros por duas colunas sobre base, sustentam um entablamento no qual aparecem três

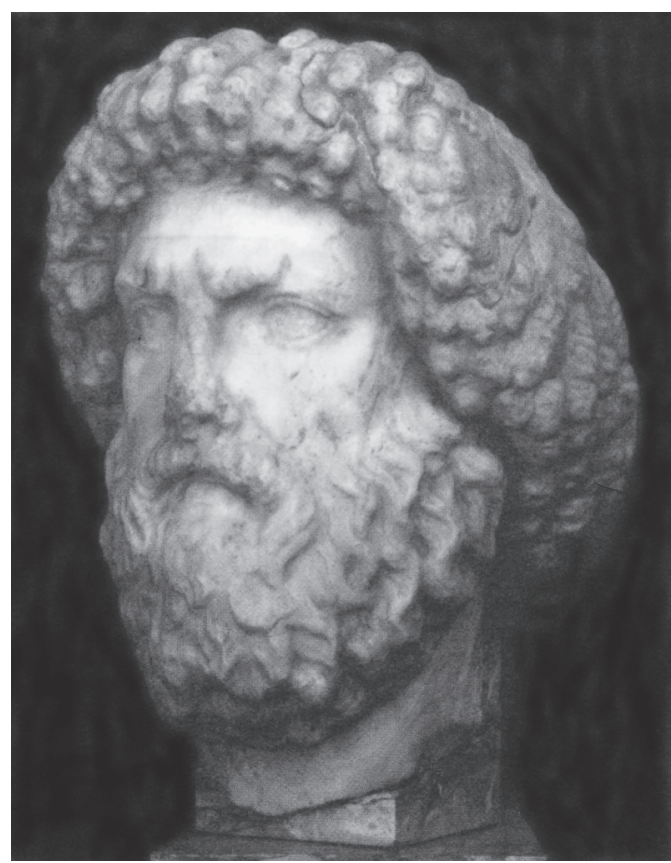

Fig. 7. Juba I. Escultura, mármore. Brett \& Fentress 1977 (1996): 44. nichos, ornados com esculturas, e limitados por colunas jônicas.

A. Bertrandy propõe, baseando-se apenas em documentação textual mencionando construções em capitais berberes, que vejamos nestas representações monumentos númidas do tempo de Juba (1980: 13). Já E. Acquaro elabora uma comparação entre estas construções e os monumentos das cidades fenícias dos emporia (Acquaro1983, apud Manfredi 1995: 199). Posteriormente, Bertrandy rende-se às evidências. Por um lado, a organização social berbere se refletia em estruturas urbanas e arquitêtonicas específicas (são as kasbas, as aldeias, os santuários a céu aberto - cf. G. Picard 1954: 6), as quais não foram ainda arqueologicamente estudadas. Por outro, apesar dos avanços feitos nas pesquisas de arqueologia púnica, conhecemos a grande arquitetura cartaginesa mormente através de outros exemplos, textuais e arqueológicos, como representações em estelas. De modo que a aproximação dos tipos iconográficos de Juba I a hipotéticas construções númidas não se sustenta. O mesmo vale para a iconografia dos grandes bronzes deste rei, que não foram batidos no sistema ponderal romano, como a prata foi. Estas peças lembram os grandes bronzes e chumbos de Massinissa, e os últimos bronzes de Cartago (são moedas de módulo grande $-37 \mathrm{~mm}$ - e peso alto $-52 \mathrm{~g}$ ). Nestes, ao templo octostilo, no anverso, corresponde o palácio dos atlantes no reverso (tipos 30 e 34).

Bertrandy busca, então, na cunhagem da Roma republicana, rica em tipos semelhantes, isto é, na figuração de construções públicas, religiosas e adminstrativas, os possíveis modelos para os tipos de Juba I. Bertrandy elencou como candidatos a Villa Publica e a basílica Aemilia, as quais aparecem em denários de prata de 55 a.C. e 61 a.C. (RRC 429/2a e 419/3b) (Bertrandy 1980: 14). Entretanto, trata-se de aproximações, não podemos assumir que Juba I tivesse tido acesso a essas cunhagens específicas e que as tivesse imitado.

Acreditamos que um jogo de imagens africanas se contrapondo a outro de romanas foi utilizado por Juba I. Uma outra série dos 
grandes bronzes, por sua vez, traz figurados dois elementos africanos: cabeça de Amon no anverso e elefante no reverso, com legenda em púnico (tipos 33 e 37). A cabeça de Amon é novidade na iconografia, mas o culto desta divindade era já muito antigo no Norte da África. Plínio, o Velho (V, 31) menciona um oráculo de Amon, a c. $500 \mathrm{~km}$ de Cirene, no oásis de Syouah, na Líbia atual, e PseudoCílax assinala um santuário de Amon próximo às Arae Philaenorum, isto é, na fronteira entre o território grego e o púnico, igualmente na Líbia atual (Périplo, 109, G.G.M. I: 85, apud Desanges 1980: 351). Grupos indígenas berberes, como os nasamões, estiveram associados a seu culto (Kormikiari 2000: 21116). Em seu acurado estudo do Saturno africano e sua associação com Baal Hammon, M. Le Glay apontou para dados que levam à interpretação que igualmente o Baal fenício teve seu culto e imagem sincretizados na figura de Amon (Le Glay 1960-1966, apud Manfredi 1995: 163). Isto é, para uma série com iconografia essencialmente romana, e de circulação garantida (a não ser que tenha sido utilizada enquanto "medalhão de prestígio", no seio da hierarquia berbere), segue outra duplamente africana. De maneira análoga, as moedas de prata com anverso de Vitória têm o cavalo livre no reverso (tipos 31 e 38); e a cabeça de África, no anverso, aparece com o leão, no reverso (tipos 29 e 36).

No entanto, estas peças são as divisionárias e não foram encontradas nos achados monetários que elencamos acima. Isto é, as peças que mais estiveram em circulação, essencialmente porque foram usadas para a paga dos exércitos, são as que trazem o retrato de Juba I e a legenda em latim, no anverso, e o templo octostilo e legenda em púnico, no reverso. Talvez Juba efetivamente quisesse estampar uma imagem de grande rei edificador. É possível que o avanço das pesquisas arqueológicas consiga, eventualmente nos esclarecer sobre o significado verdadeiro do termo "capital" berbere, que as fontes apresentam.

O último grande agellid númida, Juba I, foi morto em 46 a.C. a mando de César. Acredita- mos poder visualizar o "nacionalismo" que as fontes assinalam com relação a Juba I tanto em suas cunhagens, quanto no seu apoio a Pompeu. Conforme discutimos acima, a posse das terras, no nosso entender, esteve intrinsecamente ligada aos apoios que os reis númidas concederam aos partidos romanos em disputa.

À medida que o processo de penetração romana se intensifica na Berberia, inclusive através das guerras internas travadas em solo africano, os reis berberes criam mais tipos e tornam mais elaboradas suas cunhagens, além de passarem a utilizar, paralelamente à língua "oficial" do Norte da África (púnico e neopúnico), o latim, afinal o essencial de uma iconografia monetária é conseguir passar a mensagem pretendida. Acreditamos que os reis berberes mantiveram constante o discurso independência e autonomia, em suas moedas, adequando-o - afinal eles foram tanto agentes quanto pacientes do processo que se desenrolava ao seu redor - às mudanças políticas e conseqüentemente culturais que se seguiram na região a partir da queda do império cartaginês.

\section{Conclusões}

O primeiro rei a cunhar, Sífax, o faz ainda quando Cartago era uma potência, mas já abalada pelas Guerras Púnicas. A escolha dos tipos iconográficos de Sífax, retrato do rei e cavaleiro, demonstra fortemente o seu intuito propagandístico, e mais além, insere-se no contexto cultural e político do mundo helenístico. Tanto Sífax, como Massinissa que o suplantou (e seus sucessores), tiveram que sustentar seu poder frente às populações da Berberia: sedentários e semi-nômades. Entre estes havia as "elites", os chefes berberes menores e os cartagineses e libifenícios. Neste contexto, tanto a iconografia quanto o esforço de produção monetária dos primeiros reis númidas ganha coerência. Inicialmente as moedas de Massinissa são devedoras do 
sistema ponderal cartaginês e igualmente de sua iconografia. Nesta iconografia foram mantidas as inovações elaboradas por Sífax - o retrato e o imaginário guerreiro. No entanto, Massinissa toma posse do símbolo maior do poder cartaginês, o cavalo (ou então simplesmente copia a atitude que havia sido de Capussa, mas sempre com a intenção de auto-afirmação). A cunhagem de Massinissa, tão calcada na cartaginesa, utilizou da simplicidade e da repetição simbólica (retrato do rei/cavalo galopando), para marcar seu território.

$O$ vasto raio de penetração da cunhagem de Massinissa, nesse sentido, como vimos pelas notícias da circulação monetária, demonstra que estas peças foram aceitas e utilizadas para além do período de reino deste rei e seus sucessores, o que não ocorreu, aparentemente, com os últimos reis númidas, com exceção, talvez, de Juba I. A imagem do cavalo é, assim, um dos elementos mais fortes da cunhagem real númida de Massinissa e seus sucessores (Micipsa supostamente ficou no poder por quase 30 anos, de 148 a 118 a.C.). Ela sustenta a hipótese de que o poder real era sustentado pela força guerreira do soberano.

Por outro lado, mesmo tendo cunhado em ouro e prata, os reis númidas que se seguiram, através dos dados que a iconografia monetária nos fornecem, não mais nos parecem deter o mesmo poder guerreiro, do agellid. Como vimos, Jugurta moveu uma guerra local forte o suficiente para chamar a atenção de Roma e fazê-la mobilizar suas forças militares. Mas não encontramos nos vestígios numismáticos a mesma repercussão. A cunhagem de Hiêmpsal, ao contrário, se destaca, tanto iconograficamente quanto pela riqueza das denominações, mas com um outro caráter, o da riqueza da terra e não tanto da força guerreira. O exemplo dos reinos massilos do Ocidente é o mais significativo. Suas cunhagens demonstram uma total sujeição à sociedade urbana e à imagística local. Fica claro nesses últimos que, apesar da manutenção da legenda especificamente designando-o como "pessoa real", o rei númida não possui o mesmo poder dos seus pares orientais. Hiêmpsal II, Mastenissa e Arabion, em última instância, são os únicos a apregoarem produtos agrícolas, não militares, em sua iconografia monetária. Mas Hiêmpsal II supostamente propagandeava suas riquezas pessoais, se ele efetivamente era o dono das terras, ou coletivas, se estas eram trabalhadas a partir de relações de reciprocidade. Já os massilos ocidentais, aparentemente, apenas se sujeitaram à iconografia local.

Juba I, por outro lado, aparece como o derradeiro rei númida de fato. Sua cunhagem de prata provavelmente foi patrocinada pelos romanos. De qualquer forma ele só emite em bronze até c. 47/46 a.C., quando então bate denários em Útica para Pompeu. No entanto, tanto o numerário de prata quanto o de bronze elaboram um sofisticado jogo entre o imaginário romano e o africano. Principalmente sua caracterização pessoal, nos anversos, com a típica cabeleira númida, representa uma propaganda pessoal muito forte. Lembramos que é justamente nas peças de prata que este retrato aparece e não nas de bronze. Os achados monetários do Mediterrâneo setentrional demonstram que a intenção era a de difundir a propaganda pessoal para além da Berberia. 
KORMIKIARI, M.C.N. North Africa in antiquity: the Numidian Berber kings and their monetary iconography. Revista do Museu de Arqueologia e Etnologia, São Paulo, 17: 251-292, 2007.

Abstract: In this article we present our interpretation of the North African Berber kings' monetary iconography, focusing on the Numidian kings. They coined money between the $3 \mathrm{rd}$ and the 1 st centuries B.C.. We also deal with this coinage's connection to the Carthaginian and the Roman ones, which constituted the main circulation coinage in the area. In this sense, we deal with the ideological and cultural aspects that sustained these North African monarchies in antiquity.

Keywords: North Africa - Numidia - Coinage - Iconography - Carthage - Rome.

\section{Fontes textuais}

APIANO

1960 Apian's Roman History. The Loeb Classical Library. Londres: William Heinemann Ltd. BELL. AFRIC.

1949 Bellum Africum. Guerre d'Afrique. Texte établi et traduit par A. Bouvet. Paris: Les Belles Lettres.

ESTRABÃO

1954-1961 The Geography of Strabo. Trad. Horace Leonard Jones. The Loeb Classical Library Cambridge: Harvard University Press.

JUSTINO

s/d Abrégé des Histoires Philippiques de
Trogue Pompée et Prologues de Trogue Pompée. Paris: Librairie Garnier Frères, 2 vols.

PLÍNIO, O VELHO

1980 Histoire Naturelle. Livre V, 1-46, $1^{\text {ere }}$ partie (L'Afrique du Nord). Texto estabelecido traduzido e comentado por Jehan Desanges. Paris: Les Belles Lettres.

\section{SALÚSTIO}

1947 Guerre de Jugurtha. Org. Alfred Ernout. Paris: Les Belles Lettres.

TITO-LÍVIO

1949 Histoire Romaine. Trad. Eugène Lassere. Paris: Librairie Garnier Frères.

\section{Referências bibliográficas}

ACQUARO, A.

1983-1984 Sui 'ritratti barcidi' delle monete puniche. Rivista Storica dell'antichità, XIIIXIV: 83-86.

1983 L'espansione fenicie in África. In: Fenici e Arabi nel Mediterraneo. Roma, Accademia Nazionale dei Lincei: 23-61.

ALEXANDROPOULOS, J.

1989 Considérations sur les derniers monnayages de bronze de la Carthage punique. Bulletin. de la soc. français de Numismatique, XLIV (3): 533-539.

AMANDRY, M.; BURNETT, A.; RIPOLLĖS, P.P.

1988 Roman Provincial Coinage-RPC, vol.1: from the death of Caesar to the death of Vitellius
(44 a.C. - 69 d.C.). Part I: Introduction and Catalogue. Londres: British Museum Press.

BARADEZ, J.

1957 Nouvelles fouilles à Tipasa, Survivances du culte de Baal et Tanit au I $^{\text {er }}$ siècle de l'ère chrétienne. Lybica, Archéol. Epigr., V: 221-275.

BAYET, J.

1941 'L' omen du cheval a Carthage' Timée, Virgile et le monnayage punique. Revue Études Latines, 19: 166-190.

BERTHIER, A.; CHARLIER, R.

1952 Le sanctuaire punique d'El-Hofra à Constantine. Paris: Arts et Metiers Graphiques. 
BERTRANDY, F.

1980 Remarques sur l'origine romaine du monnayage en bronze et en argent de Juba I ${ }^{\text {er }}$, Roi de Numidie. Bulletin Archéologique, 12-14, 1976-1978: 9-21.

1986 A propos du cavalier de Smithus (Chemtou). Antiquités africaines, 22: 57-71.

BRETT, M.; FENTRESS, E.

1996 The Berbers. Oxford: Blackwell, The Peoples of Africa series.

BURNETT, A.

1987 Africa. The Coinage of the Roman World in the Late Republic. Proceedings of a Colloquium held at the British Museum in September 1985. BAR International Series, 326: 175-185.

CAGNAT, R.

1909 Remarques sur les monnaies usitées dans l'Afrique romaine à l'époque du Haut Empire. Klio, 9: 194-205.

CAMPS, G.

1960 Massinissa ou les débuts de l'histoire. Lybica, VIII.

1961 Aux origines de la Berbérie. Monuments et rites funéraires protohistoriques. Paris: Arts et Métiers Graphiques.

1973 Nouvelles observations sur l'architecture et l'âge du Medracen, mausolée royal de Numidie. Comptes rendus de l'Académie des Inscriptions: 470-516.

1980 Berbères. Aux marges de l'histoire. Toulouse: Ésperides.

1984 Les derniers rois numides: Massinissa II et Arabion. Bulletin Archéologique du Comité des travaux Historiques et Scientifiques, 17B: 303-311.

CARCOPINO, J.

1943 Le Maroc antique. Paris: Gallimard.

CARONNI, F.

1805 Raguaglio del viaggio compendioso di un dilettante antiquario. Milão: Sonzogno.

CHEYNE, T.K.; SUTHERLAND, J.

1901 Encyclopaedia Biblica, II. Londres, Adam and Charles Black: v. cavalo.

COARELLI, F.; THÉBERT, Y.

1988 Architecture funéraire et pouvoir: réflexions sur l'hellénisme numide. Mélanges de l'école française de Rome, C (2): 761-818.

DECRET, F.

1977 Carthage ou l'empire de la mer. Paris: Éditions du Seuil.

DESANGES, J.

1962 Catalogue des tribus africaines de l'antiquité classique à l'ouest $d u$ Nil. Publications de la section d'histoire de la Faculté des Lettres et Sciences humaines de l'Université de

Dakar, n.4, Dakar.

1980 Permanence d'une structure indigène en marge de l'administration romaine: la Numidie traditionalle. Antiquités Africaines, 15 (b): 77-89.

1983 Os protoberberes. In: Mokhtar, G. (Coord.) História Geral da África. IV. A África antiga. Comitê Científico Intenacional para a Redação de uma História Geral da África (Unesco). São Paulo/Paris: Ática/Unesco, vol.2.

FENTRESS, E.W.B.

1982 Tribe and Faction: the Case of the Gaetuli. Mélanges de l'école française de Rome, XCIV: 325-334.

FISCHER, B.

1978 Les monnaies antiques d'Afrique du Nord trouvées en Gaule. Suplemento de Gallia, XXVI.

GALAND, L.

1989 Les alphbets libyques. Antiquités Africaines, 25: 68-81.

GERIN, D.

1989 Le monnayage des rois numides: trésors et chronologie relative, (resumé). Bull. de la soc. française de Numismatique, XLIV (3): 509-510.

GSELL, S.

1920/1927 Histoire ancienne de l'Afrique du Nord. Paris: Hachette, 8 vols.

HALL, J.

1997 Ethnic Identity in Greek Antiquity. Cambridge: Cambridge University Press.

IGCH

1973 An Inventory of Greek Coin Hoards. Thompson, M.; Morkholn, O.; Kraay, C.M. (Orgs.) New York: The American Numismatic Society.

ISSERLIN, B.S.J.

1983 Un cas douteux d'enterprise maritime carthaginoise: la prétendue trouvaille de monnaies carthaginoises à Corvo (Açores). BCTHS, 19B: 25-28.

JENKINS, G.K.

1972 Ancient Greek Coins. Fribourg: Office du Livre.

1987 Some Coins of Hannibal's time. Bolletino di Numismatica, Suplemento p/o vol. IV (Studi per Laura Breglia), I: 215-234.

JENKINS, G.K.; LEWIS, R.B.

1963 Carthaginian Gold and Electrum Coins. Revue Suisse de Numismatique, publicação especial n. 2. 
JODIN, A.

1987 Volubilis regia Iubae. Paris: Diffusion de Boccard.

KONTORINI, V.N.

1975 Le roi Hiempsal II de Numidie et les Rhodiens. L'Aniquité Classique, XLIV: 89. 99.

KORMIKIARI, M.C.N.

$2000 \quad$ Norte da África autóctone do século III ao I a.C.: as imagens monetárias reais berberes. Tese de Doutoramento na Área Interdepartamental de Arqueologia apresentada à Faculdade de Filosofia, Letras e Ciências Humanas da Universidade de São Paulo.

KOTULA, T.

1976 Les africains et la domination de Rome. Dialogues d'Histoire ancienne, II: 337-358.

KRINGS, V. (ED.)

1995 La civilisation phénicienne et punique. Manuel de recherche. Nova Iorque: E.J. Brill.

LASSÈRE, J.-M.

1982 L'organisation des contracts de population dans l'Afrique romaine, sous la République et au Haut-Empire. ANRW, II, 10 (2): 397-426.

LE GLAY, M.

1960-1966 Saturne Africain. Monuments, vols. III. Paris: Éditions de Boccard.

1964 La dea Africa à Timgad. In: Renard, M.; Schilling, R. (Eds.) Hommages à J. Bayet. Bruxelas, Latomus: 374-382.

MACKIE, N.K.

1983 Augustan colonies in Mauretania. Historia, XXXII: 332-358.

MANFREDI, L.I.

1995 Monete Puniche, Repertorio Epigrafico e Numismatico delle Leggende Puniche. Roma, Bollettino di Numismatica, Monografia 6. Rep.

MAZARD, J.

1955 Corpus Nummorum Numidae Mauretaniaeque. Paris: Arts et Metiers Graphiques.

1957 Essai de reclassification méthodique des monnaies de Numidie et de Mauretanie. In: Babelon, J.; Lafaure, J. (Eds.) Actes du Congrès International de Numismatique, Paris, 6-11 julho, 1953. Paris, Comission Internationale de Numismatique, Socièté Française de Numismatique et Bibliothèque Nationale: 153-164.

1960 Création et diffusion des types monétaires maurétaniens. Bulletin d'archéologie Marocain, IV: 107-116.
MAZARD, J.; LE GLAY, M.

1958 Les portraits antiques du Musée Stéphane Gsell d'après les sculptures et les monnaies, Les conférences-visites du Musée Stéphane Gsell, 1956-1957, IX. Alger: Imprimerie Officielle.

MILDENBERG, L.

1957 Les inscriptions des monnaies carthaginoises. In: Babelon, J.; Lafaure, J. (Eds.) Actes du Congrès International de Numismatique, Paris, 6-11 julho, 1953. Paris, Comission Internationale de Numismatique, Socièté Française de Numismatique et Bibliothèque Nationale: 149-151.

MÜLLER, L.

1861 Numismatique de l'ancienne Afrique. Bologna: Armaedo Forni Editore, 1964 (1a ed. 1861), 3 vols.

PEREZ, C.

1989 La monnaie de Rome à la fin de la Republique. Paris: Éd. Errances.

PICARD, G.C.

1954 Religions de l'Afrique antique. Paris: Plon.

1983-1984Hannibal hégémon hellénistique. Rivista Storica dell'Antichità, XIII-XIV: 75-81.

POLITT, J.J.

1986 Art in the Helenistic Age. Cambridge: Cambridge University Press.

ROSSETTI, S.

1960 La Numidia e Cartagine fra la II a e la III ${ }^{a}$ guerra punica. Parola del Passato: 336-353.

RRC

1975 Crawford, M.H. Roman Republican Coinage. Cambridge: Cambridge University Press.

SMADJA, E.

1983 Modes de contact, sociétés indigènes et formation de l'État numide au seconde siècle avant notre ère. Modes de contact et processus de transformation dans les sociétés anciennes, Actes du Colloque de Cortone, 24-30 maio de 1981. Pisa/Roma, École française de Rome: 685-702.

THOMAS, G.

1949 Sur une trouvaille de monnaies numides. Revue Numismatique: 114-119

TROUSSEL, M.

1948 Le trésor monétaire de Tiddis. Recueil des Notes et Mémoires de la Société archéologique de Constantine, LXVI: 129-176.

VILLARONGA, L.

1973 Las monedas hispano-punicas. Barcelona: Asociación Numismatica Española. 
VISONÀ, P.

1998 Carthaginian coinage in perspective. American Journal of Numismatics, Second Series, 10: 1-27, pranchas.

VOISIN, J.-L.

1983 Le triomphe africain de 46 et l'idéologie césarienne. Antiquités Africaines, 19: 7-33.

Recebido para publicação em 12 de setembro de 2007.

\section{VUILLEMOT, G.}

1953 Note sur un lot d'objets découverts à Siga. Bulletin de la Société de Géographie et d'Archéologie d'Oran (B.S.G.A.), LXXVI: 23-25. WHITTAKER, C.R.

1993(1978) Land and Labour in North Africa. In: Land, City and Trade in the Roman Empire. Aldershot, Variorum: 331-362. 